
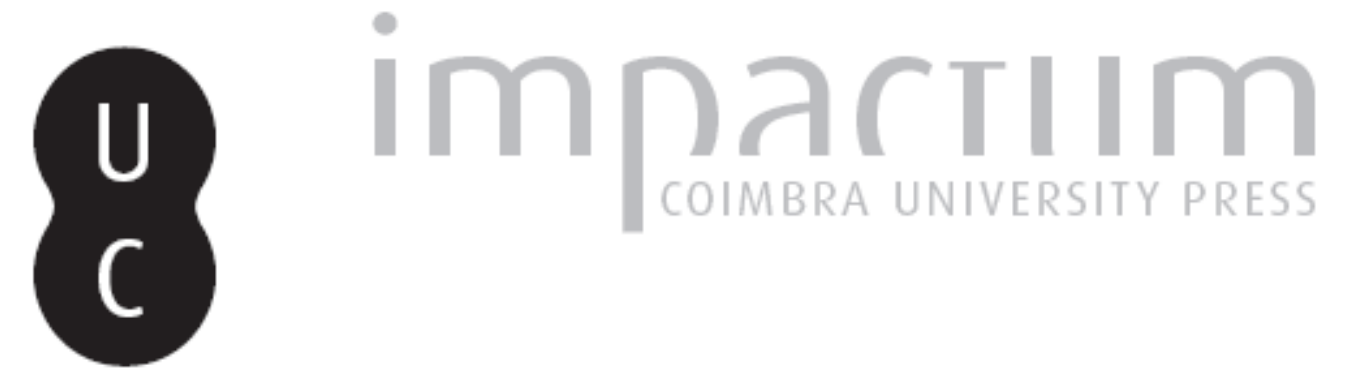

\title{
Digital Alberti: tradition and innovation in the architectural theory and practice in Portugal
}

\author{
Autor(es): $\quad$ Krüger, Mário
}

Publicado por: Editorial do Departamento de Arquitetura

URL persistente:

URI:http://hdl.handle.net/10316.2/37246

DOI:

DOI:http://dx.doi.org/10.14195/1647-8681_5_18

Accessed : $\quad$ 26-Apr-2023 00:17:44

A navegação consulta e descarregamento dos títulos inseridos nas Bibliotecas Digitais UC Digitalis, UC Pombalina e UC Impactum, pressupõem a aceitação plena e sem reservas dos Termos e Condições de Uso destas Bibliotecas Digitais, disponíveis em https://digitalis.uc.pt/pt-pt/termos.

Conforme exposto nos referidos Termos e Condições de Uso, o descarregamento de títulos de acesso restrito requer uma licença válida de autorização devendo o utilizador aceder ao(s) documento(s) a partir de um endereço de IP da instituição detentora da supramencionada licença.

Ao utilizador é apenas permitido o descarregamento para uso pessoal, pelo que o emprego do(s) título(s) descarregado(s) para outro fim, designadamente comercial, carece de autorização do respetivo autor ou editor da obra.

Na medida em que todas as obras da UC Digitalis se encontram protegidas pelo Código do Direito de Autor e Direitos Conexos e demais legislação aplicável, toda a cópia, parcial ou total, deste documento, nos casos em que é legalmente admitida, deverá conter ou fazer-se acompanhar por este aviso.

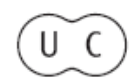




\section{Digital Allberti}

'Tradition and innovation

in the architectural theory

and practice in Portugal

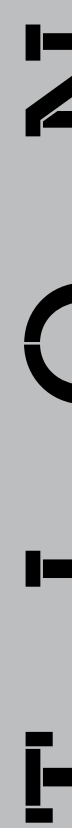

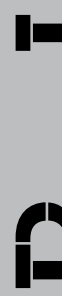

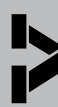


Period

2010-2013

\section{Coordinator}

Mário Krüger

\section{Researchers team}

Bruno Araújo, Bruno Figueiredo, Eduardo Castro e Costa, Giovana de Godoi, Gonçalo Canto Moniz, Hélder Carita, Joaquim Jorge, José P. Duarte, Luís Ferreira, Maria Calado, Nelson Mota, Filipe Coutinho e Vitor Murtinho

\section{Goals}

This research project is a celebration and an innovation. A celebration in the sense of commemorating the order given by King John III, in mid XVI century, to André de Resende to translate Alberti's De re aedicatoria to the Portuguese language.

An innovation in the sense of producing, for the first time, an intelligent computational environment to understand the cultural impact of this treatise on classical architecture in Portugal and abroad.

Research developes in six approaches: Alberti and the De re aedicatoria; New digital technologies; Grammar of sacred spaces; Grammar of column systematization; Architecture for a modern humanism; The virtual reality of Albertian Architecture.

\section{Conclusions}

The influence of the treatise De re aedificatoria by Leon Battista Alberti, originally published in 1485 and without illustrations, was investigated by using a computational environment to build a shape grammar, not only to decode that text, but also to understand its influence on Portuguese architecture of the counter-reformation using for this purpose the instruments given by the construction of a generative grammar of form. This allowed, for the first time, to evaluate the transformations, within the classical architecture, of the proposals suggested by that treaty and by the buildings designed and constructed in Portugal and the overseas territories.

\section{Results}

A mobile exhibition was held showing the ascendancy of this treaty in the religious architecture of that period, as well as was promoted an international conference attended by the entire research team and by international experts. The results were debated and published in more than 30 conference and journal papers. Two educational software were built in relation with the shape grammars. 


\section{Budget \\ $161.636,00 €$}

\section{Funding body}

Portuguese Foundation for Science and Technology

\section{Partners}

Centre for Social Studies (CES)

Faculty of Sciences and Technology, University of Coimbra (FCT/UC)

Instituto de Engenharia de Sistemas e Computadores, Investigação,

Desenvolvimento em Lisboa (INESC ID/INESC/IST/UTL) and

Instituto Superior Técnico (IST/UTL)

Faculty of Architecture, University of Lisbon (FAUL)

\section{Exposições/Exhibitions}

Science Museum, University of Coimbra, Abril-June 2013

Faculty of Architecture, University of Lisbon, June-September 2013 MUHNAC - National Museum of Natural History and Science I,

November 2013 - February 2014

Este dossier é parte do projeto "Alberti Digital" financiado pela Fundação para a Ciência e Tecnologia (FCT), COMPETE/FEDER, Portugal, e alojado no CES da Universidade de Coimbra (PTDC/AURAQI/108274/2008). O projeto é coordenado por Mário Krüger 
$z_{1}$

)

]

=

=

n

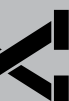

آيا 

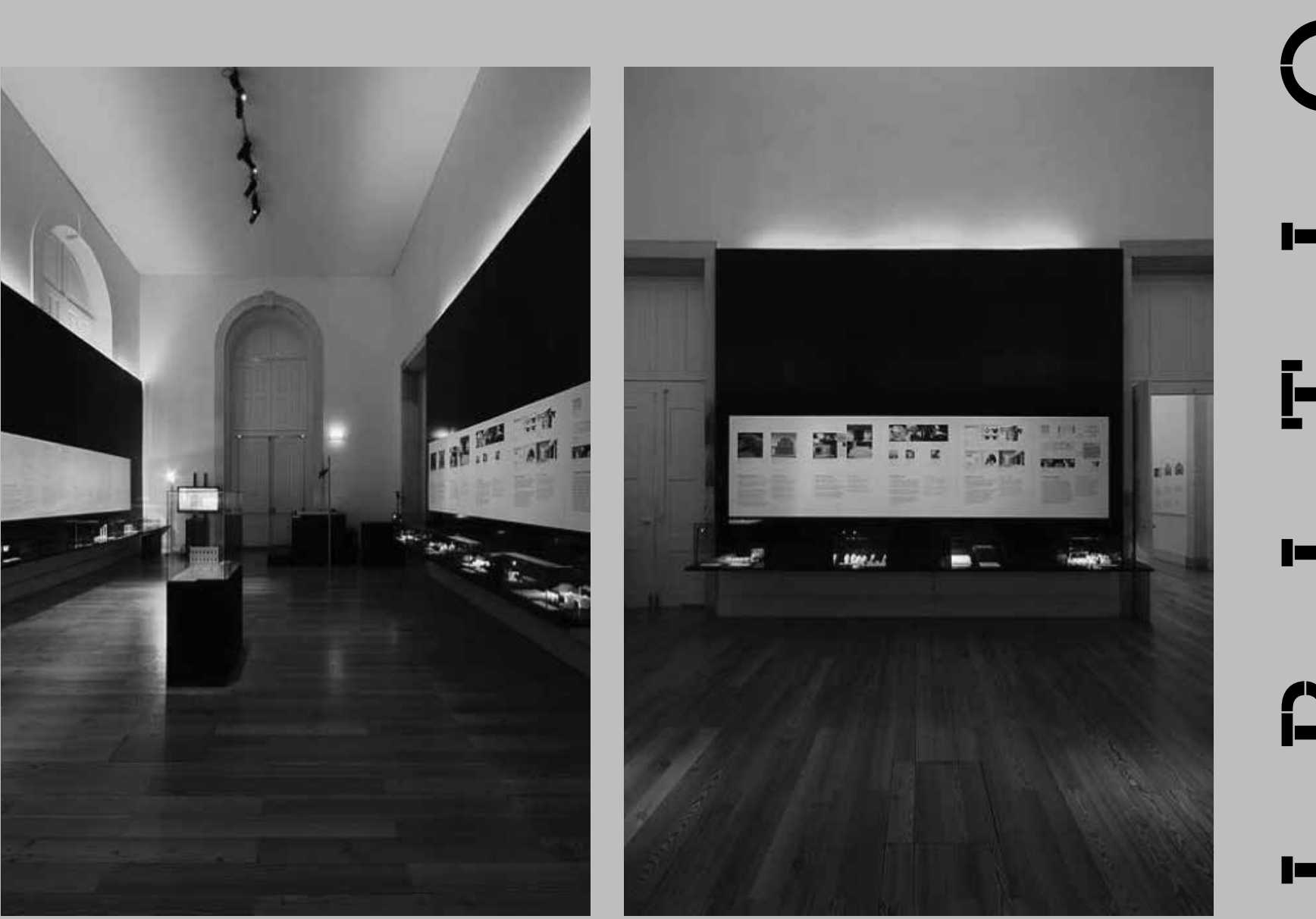

Science Museum, University of Coimbra

Coimbra, 2013 @ do mal o menos

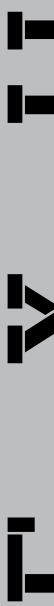



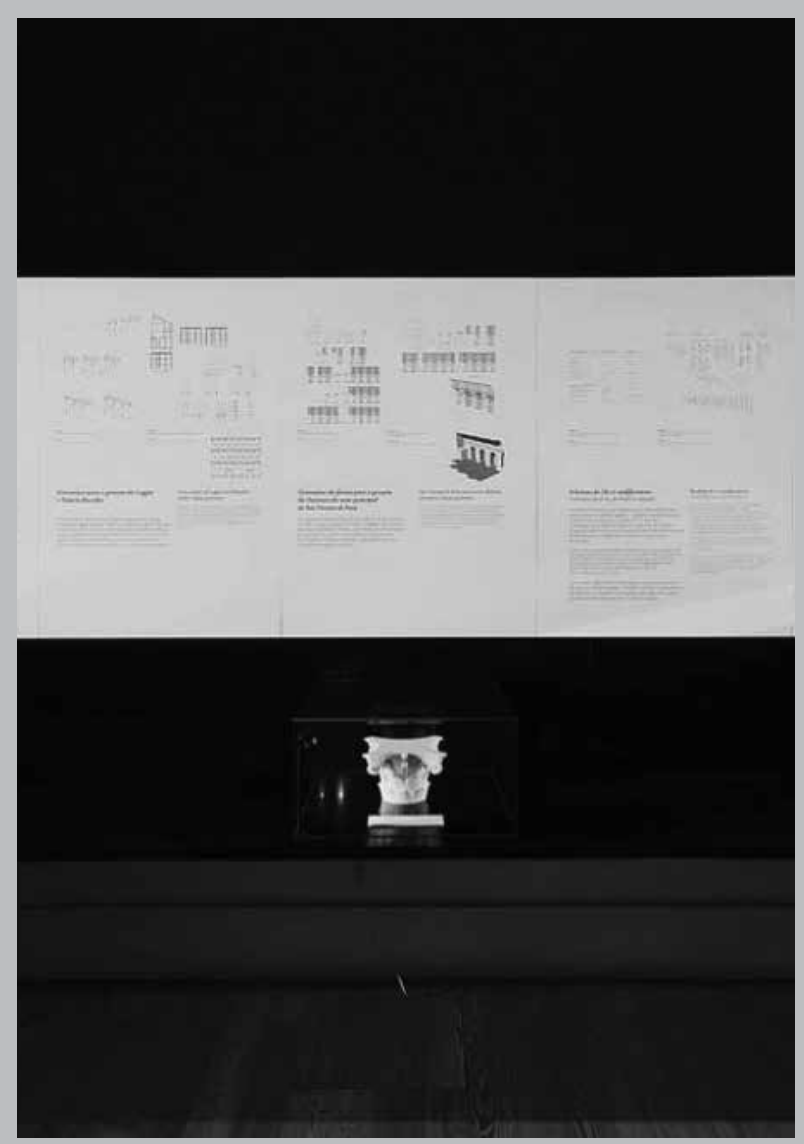

Science Museum, University of Coimbra Coimbra, 2013 @ do mal o menos

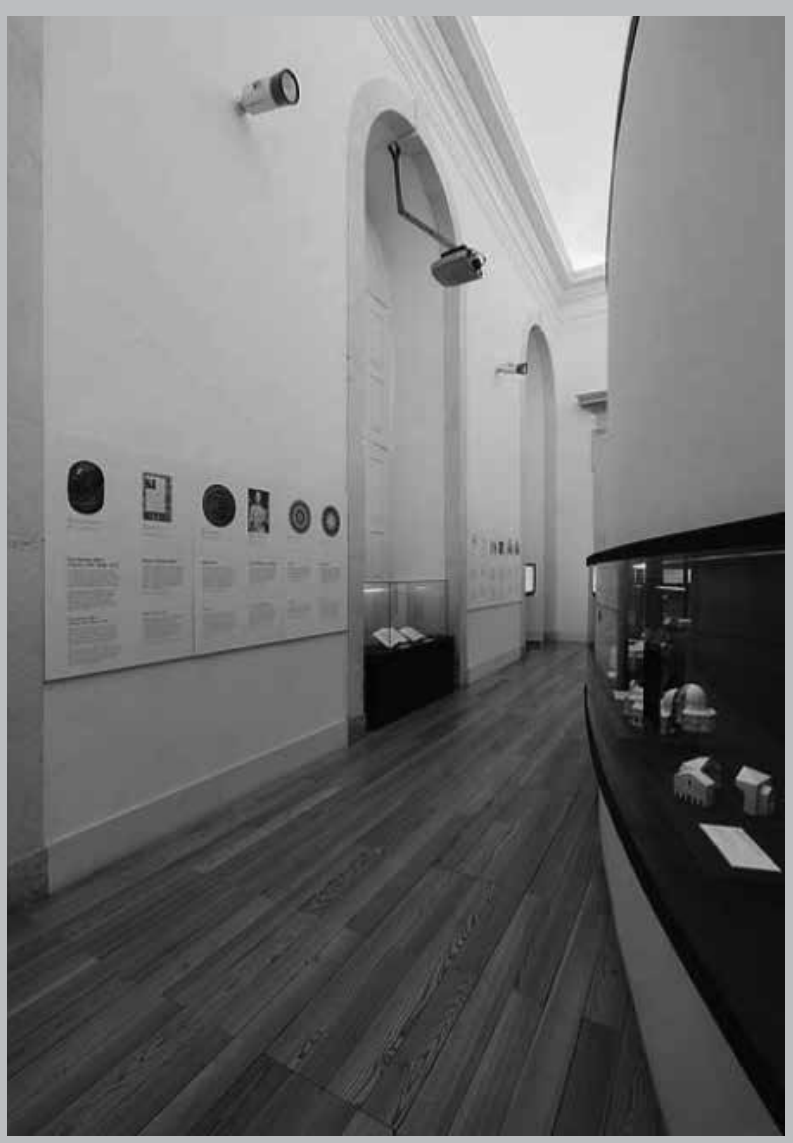

\section{ㅁำด}

$\overline{\underline{ }}$ 

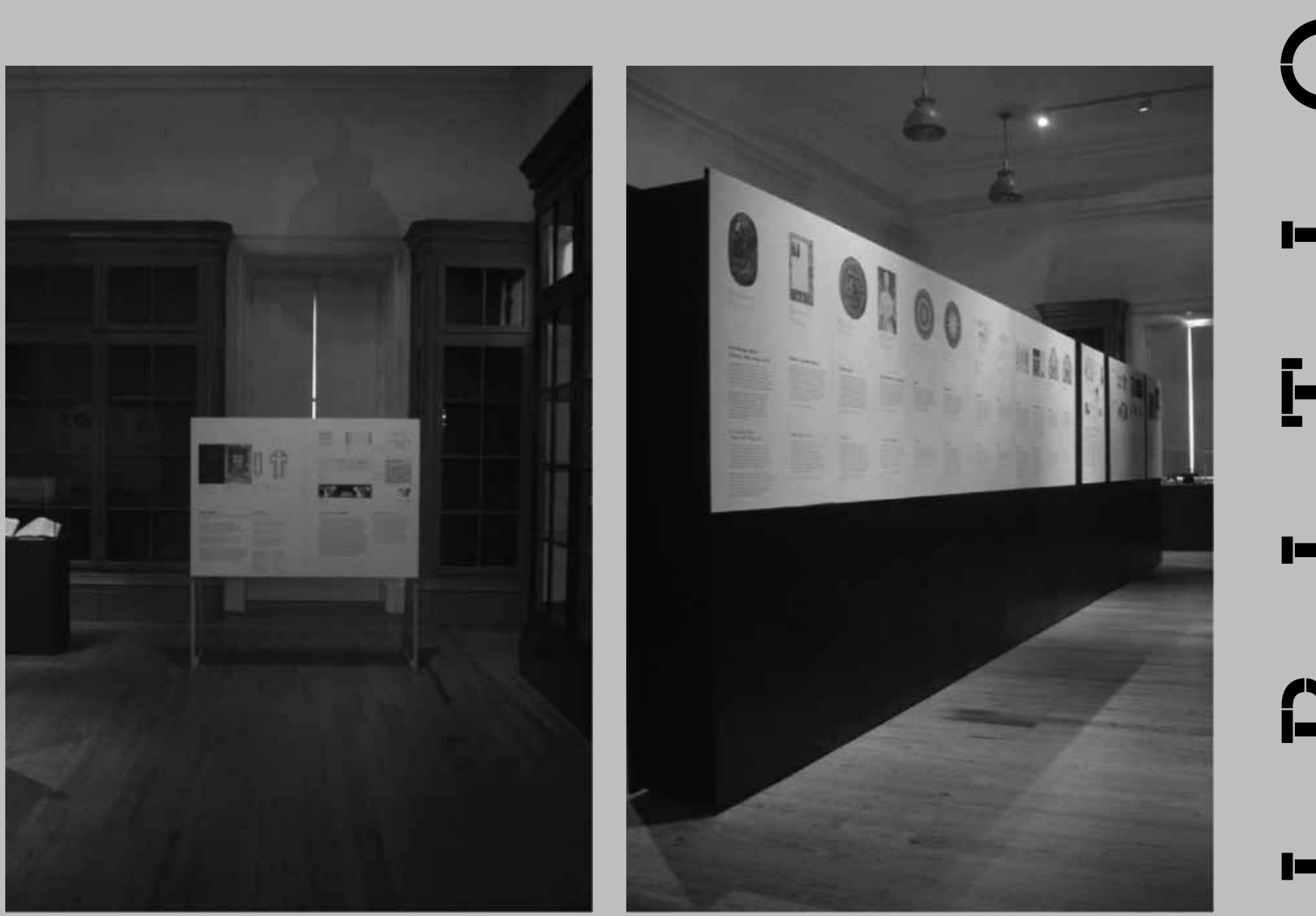

Science Museum, University of Lisbon

Lisbon, 2013-2014@ Digital Alberti Project
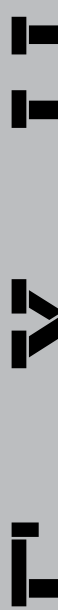
Science Museum, University of Lisbon

Lisbon, 2013-2014@ Digital Alberti Project
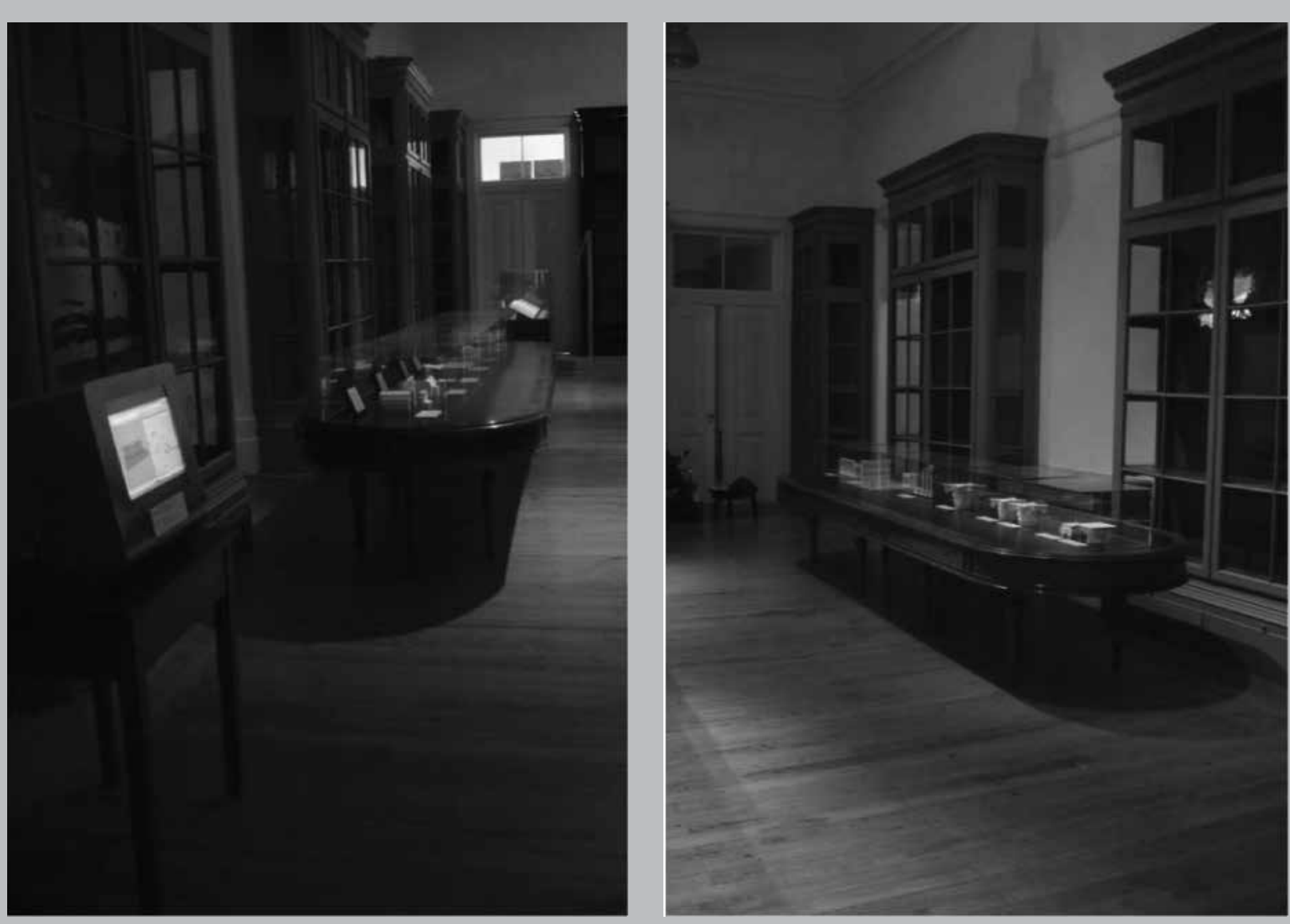


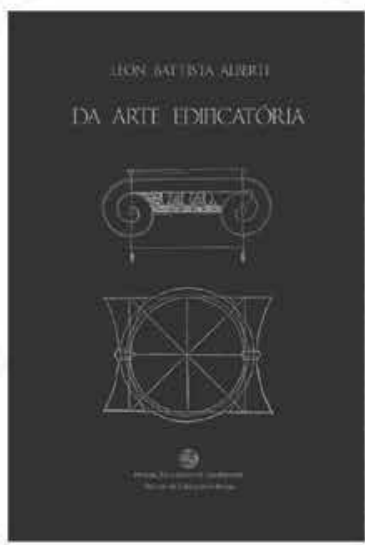

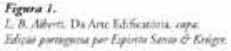

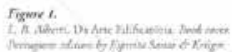

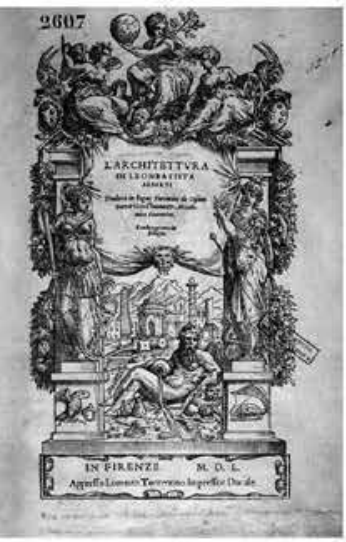

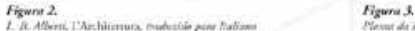

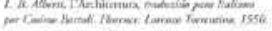

Piger 2.
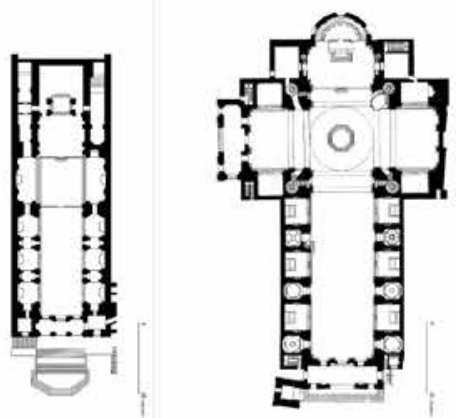

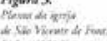

Figures Youn
Figent d.

Figurst

\section{Alberti Digital}

Tradiçāo e inovaçáo na teoria e prática da Arquitectura em Portugal

Este projecto de investigaçáo é, simultaneamente, uma celebraçáo e uma inovaçáo. Uma celebração no sentido de comemorar a ordem dada por D. Joáo III, em meados do séc. XVI, a André de Resende para traduzir para português o De re Aedificatoria de Leon Battista Alberti.

Uma inovaçăo no sentido de produzir, pela primeira vez, um ambiente computacional inteligente para se entender o impacto cultural deste tratado na arquitectura clássica, tanto $\mathrm{em}$ Portugal como no ultramar.

Este projecto tem por objectivo traçar a influência da teoria de Alberti na arquitectura clássica em Portugal usando um ambiente computacional para construir uma gramática generativa da forma, que possibilite entender as transformaçóes entre as suas propostas de organizaçáo formal e os edificios projectados e construidos, tanto $\mathrm{cm}$ Portugal como naqueles territórios ultramarinos.

\section{Digital Alberti}

Tradition and innovation in the architectural sheory and practice in Portugal

This research project is a celebration and an innovation.

A celdbation in the sense of conmemorating the order given by King John III, in mid XVI century, to André de Resende to translate Alberti's De ne acdificatoria to the Portuguesc language.

An innovarion in the sense of producing for the first time, an intelligent computational environment to understand the cultural impact of this reative on classical archieccrure in Portugal and abroad.

This project aims to trace that intluence of Alberti's theory in Portuguese classical atchitectute using a computational environment to constract a ecocrative shape grammar which will enable to understand the transformations berween the treatixe and the buildings doigned and buils in Ponugal and everseis

A investigaçâo desenvolve-se Researchi developes em seis abordagens: in six approachest

= Alberti co De re aedificatoria $=$ Alberti and the

- Novas Tecnologias digitais De re aedificatoria

- Gramática dos espaços - New digital Technologies

Sagrados - Grammar of Sacred spaces

= Gramática da sistematizaçáo = Grammar of Column

da Coluna systematization

- Arquitectura para um

Humanismo Moderno

- A Virtual Realidad.

- Architecuure for a Modern Humanism

- The Virrual Reality

da Arquitectura Alberriana Architecture Albertian 


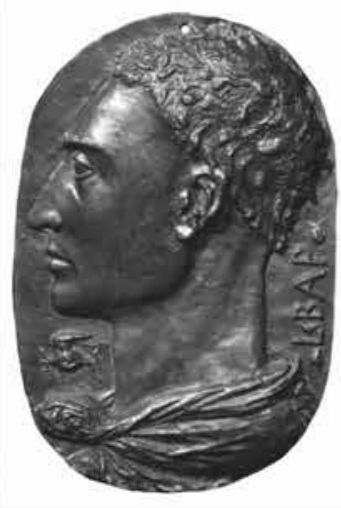

Foguret. 1 .

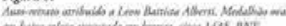

Finerr $t$.

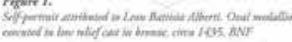

\section{Leon Battista Alberti \\ (Génova, 1404 - Roma, 1472)}

Considerado pelos seus contemporàneos como tendo uma criatividade inoomensurável pelo cultivo dos mais diversos saberes disciplinares e dos mais variados conhecimentos literários, por mais indecifríveis e improviveis que fossem. é o autor do tratado De re aedificatoria, publicado $\mathrm{cm} 1485$, que abriu as portas $\mathrm{da}$ modernidade $\mathrm{em}$ arquitectura, pela forma inovadora como sistematizou, com inteligibilidade e eloquência, a arte edificatória.

Com um estatuto inaugural em relaçío ao corpus de referència disciplinar, esta obra de Alberti é baseada na hierarquizaçio intransitiva entre o prazet, a comodidade e a necessidade, bem como na natureza - no corpo animal, - na história,

- na arquitectura dos Antigos, - e ainda na harmonia

das partes com o todo, de modo a que o edificado edifique. isto $e ́$, tenha e dé dignidade a quem concebe ou promove edificios de admiraivel beleza.

\section{Leon Battista Alberti \\ (Genoa, 1404 - Roma, 1472)}

Regarded by his contemporaries as having an immeasurable creativity by cultivating knowledge from various disciplines and the most varied literary attainments, however improbable and indecipherable they wete, is the author of the treatise De er aedificateria, published in 1485 , which opened the doors of modernity in anchitecture, systematizing in an innovative way with intelligibility and eloquence, the art of building.

With an inaugural status in relation to the corpus of written works in architecture, this treatise is based on the hieratchy between pleasure, convenience and necessity, as well as in nature - the animal body - in history - the architecture of the Ancients - and yet, in harmony of parrs ro the whole, so that the builc work edific. that is, has and gives dignity to those who design buildings or promote them with admirable beauty.

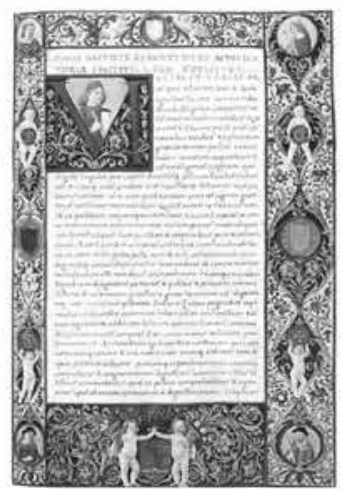

Figune 2.

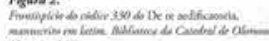

Figanz 2

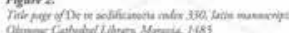

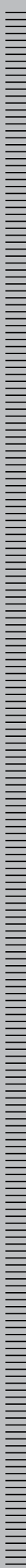

\section{Multas et Varias Artes}

Many and sarions arb, which belp to make she conose of our life mom agreable and checrfil were handed down to us by our ancorton who had acquired them by mudh efforr and care.

I need not specify thres arb: it is obvious which they are Yet, if you reflect on it, you wovild nor find one among all the most important arts that did not seck end consider its onen particular endis, exduding anything elie. If. however, jou were erentually to find any that proved wholly indispensable end yet uxre capable of uniting wse with pleassure as well as bonor. I bhink you could not omit anchitecture from that cattegon.

L. B. Alberti, On the Ant of Building in Ten Book, Prologue. 


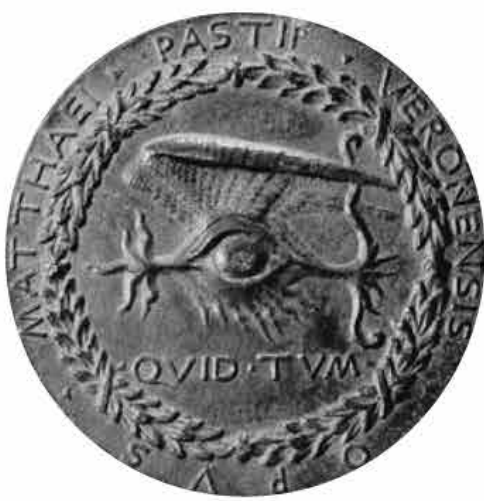

Figura 3.

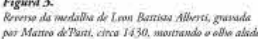

Figure 3.

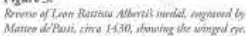

\section{Delineamento}

O delineamento náo depende intrinsecamente da materia, mas é de indole tal que nos damos conta que em vários edifficios existem as mesmas linhas, quando neles se verifica una só e mesma forma, isto é, quando as suas partes, $e$ a disposiçáo e ordenamento de cada uma delas correspondem entre si em todos os seus angulos e limhas, E serd legitimo projectar mentalmente todas as formas independentemente de qualquer matéria; consegui-lo-emos desenhando e pré-definindo ángulos e linhas com uma orientaḉo e uma conexáo exactas. Assim sendo, segue-se que o delineamento seri un trafado exacto e uniforme, mentalmente concebido, constituido por linhas e àngulos, levado a cabo por uma imaginafáo e intelecto cultos.

L. B. Alberti, Da Arse Edificatória, Livro I, Cap. 1.

\section{Lineamenta}

Nos do lineaments bave anything to do with material

but they are of such a nature that we may recognize the same lineaments in several different buildings that share one and the same form.

that is, when the parts, as well as the siting and order, correspond with one another in their every line and angle. It is quite posible to pnoject whole forms in the mind without any recourse to the material. by designating and determining a fixed orientation and conjanction for the varrious lines and angles. Since that is the case, let lineaments be the precise and correct outline, conceived in the mind, made up of lines and angles, and perfected in the learned intellect and imagination.

L. B. Alberti. On the Art of Building in Ten Books, Book L, Chapter 1.

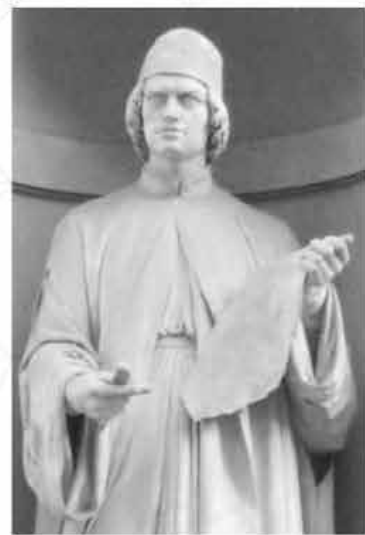

Figunt 4

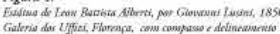

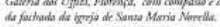

Figure 4.

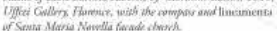

\section{Do Delineamento e Construçáo}

A arte edificatória, no seu todo, compöe-se de delineamento e construçâ. Toda a funçáo e razío de ser do delineamento resume-se em encontrar um processo, exacto e perfeito, de ajustar e tonir entre si linhas e ângulos. afim de que, por meio daquelas e destes, se possa delimitar e defrnir a forma do edificio. Ora é funçáo e objectivo do delineamento prescrever aos edifficios e às suas partes uma localizaçâo adequada e proporłâa exacta, uma escala conveniente e uma distribuiçáo agradavel. de tal modo que a conformaciá de todo o edificio assente unicamente no próprio delineamento.

L. B. Alberti, Da Arte Edificatória, Livro I, Cap, 1.

\section{De Lineamentis Aedificiorum}

On the art of building, is composed of lineaments and structure. All intent and purpose of lineamenss lies in finding the correct, infallible way of joining and fitting together those lines and angles which define and enclose the surfaces of the building. It is the function and duty of lineaments, then, to prescribe an appropriate place. exact numbers, a proper scalle, and a graceful onder for whole buildings and for each of their constituent parts, so that the whole form and appeanance of the building may depend on the lineaments alone.

L. B. Alberti, On the Art of Building in Ten Books, Book I, Chapter 1 . 


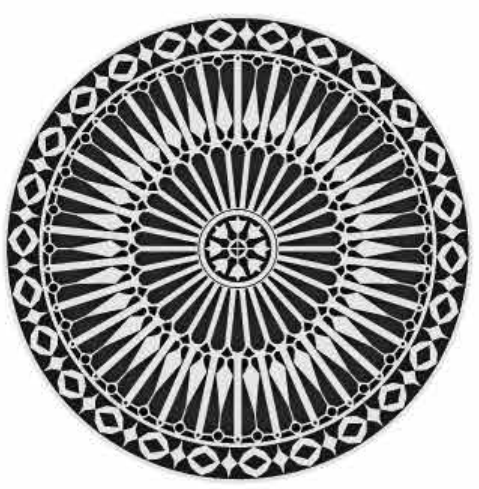

Figuna 5.

now Flempip

Figures.

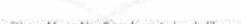

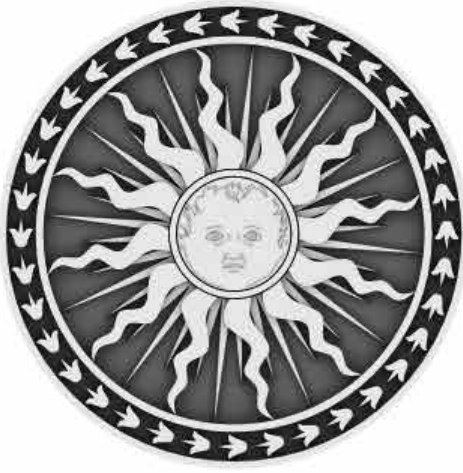

Figuran a

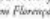

Figue 6

Concinidade

Säo tris as principais nocojes en que se condensa na totalidade aquele principio que buscamos: numero, aquilo a que chamamos delimitaçâ, edisposicia Mas há qualquer coisa mais en virzude da qual, a parrior da junção e ligąáo dessas trés nọ̄és, resplandece manavilhosamente toda a face da beleza: e nós dar-the-emos a designạ̦áo de concinidade e dela mesma dizemos que filha de soda a gratca e decoro. Além disso, é funcäo cobjective da concinidade ordenar as partes, gue de outro modo sáa, por natureza, distintas entre si, segundo uma norma táo perfeita que umas correspondam ao ornamento das outnas

L. B. Alberdi, Da Arte Edificatoria, Livio IX, Cap, 5.

\section{Concinnitas}

Finm this may conclude, without mty pursuing such questions any longet that the three principal components of that whole theory into which we incuire are number, what we might call outline, and position. But arising from the composition and connection of these three is a further avalisy in which beany shines fill fuce: our term for this is concinnitas: which we saty is nourrished with every gratee and splendor. It is the sask and aim of concinnitas to compose parts they are quite sepanate from each other by their nature, according to some precise rites so that they correspond to one another in appearince-

1. B. Alberti, On the Art of Building in Ten Books, Book IX. Chapter 5 . 


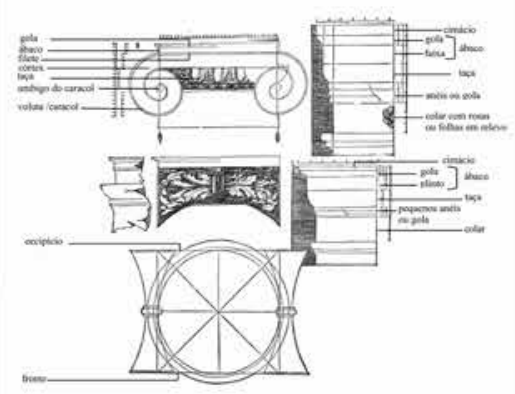

Figurst

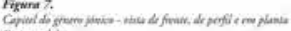

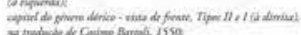

Figare 7.

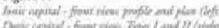

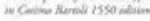

\section{Língua Latina}

Prometi que queria, quanto de mim depende, expresar-me em latim ede manrina tal que fosse entendido. Por isso, soma-se necossdrio forjar palavnas quando as de uso comum náo sáo suficientes; e convem tomar as semelhanças dos vocíbulos de coists naio disemelhantes. Entre nés, Toscamos, chama-se nastro a uma fita muito fina com que as nuparigas prendem e seguram o cabelos por isse, se nos é permitido, chamemos nastro (filete) à fatixa que, como uma opérie de rigua curva cinge o tornazelo da columa coma se fosse um and. E chamaremos colarinho ao and que. por cima do filete, circunda a volta superior da colsuna, como se fosse um cordel enrolado.

L. B. Alberti, Dat Arte Edificatória, Livro VI, Cap. 13.

\section{Latinus Sermo}

Thave sold you that I desire to mutke my langrange Lasin. and as clear as poossible, so as to be nasily anderstood. Words must therefore be inented, wher those in current wse are inadequates it will be best to draw them from familiar things. We Tiscans call filles the natrow band with which matidens bind and dress their hati, and se, if tur may, Set ws call "filles" the plat buand that encintes the onds of the column like boop. But the ring positioned at the sop neat to the fillet, which binds the sop of the shaft like a swissed cord. les we call "collarr."

L. B. Alberti. On the Art of Building in Ten Books. Book VI. Chapter 13

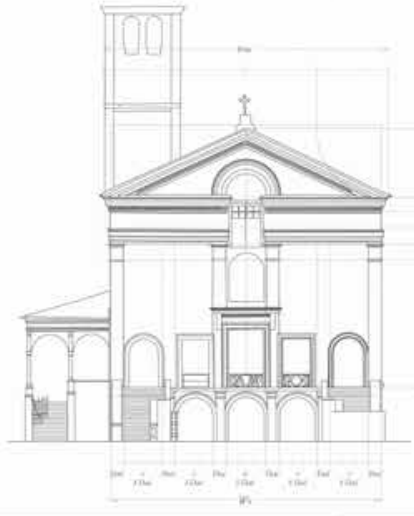

Figuna \&

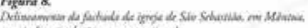

Figeres \&

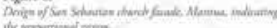

\section{Música}

Os numeros, pelos quais se faz com que a concinidade das vozes se torne agradabilissima nos ouvidos, säo os momos que fazem com que os olhas e o eppirito se encham de um pruzer manuvilhoso. O principio da delimitapào seni tinado inteinamente da musica, na qual otes nimcras soo utilizadissimos co além disso daquilo em que a natureza of erceca por si mesma algo notivel e digno.

L. B. Alberti, Da Arte Edificatória, Livro IX, Cap. 5.

\section{Musica}

The wery same mumbers that canse sounds fo have thas concinaitas. pleasing to the ears, can also fill the ores and mind with wondrows delight. From musitians phenfore who base already earnined such numbers thoroughily ar from those objects in which Nanure has displayed some criden and noble quality the whole method of outlining is derined.

1. B. Alberti, On the Ars of Building in Ten Books, Book IX Chapter 5. 


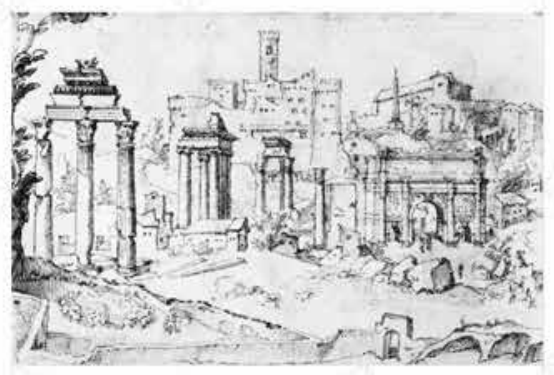

Figume 9

Figerer 9

\section{Obra Antiga}

De resta, fudo isto se deve pồ em pritica de onde quer que existisce uma abna antiga em que brillhusse unna centelha de valor, imediatamente me puntua a compulsd-la pana ver se com ela podia aprender algama coisa. Por isso, nado cessatua de explonar tudo, de observar atentamente. de medir, de fazer un oboga, ate aprender econbecer em profundidad o contributo de cada um an engenho e arte; edeste modo suavizant o traballio com o dscigo e o prazer de aprender. E nat verdade reanir num tooto coisas tâo variadas, tâo dispares, tâo dispersas, täo alheias at priticate as conhecimento dos autores, examind-las de maneinz conveniente, e dispó-has em orden adequadda, e matd-las em linguagem cuidada, e axpó-las segundo um método certo - e sem divida algume próprio de capacidade e saber superiones às que notonheco om mim.

L. B. Alberti, Da Arte Edificatoria, Livro VI, Cap. 1.

\section{Antiquorum Operum}

No bailding of the ancients that had attracted praise, wherevet it might be but l immediately aramined is carefully to sec what I could learn from it. Therefore I never stopped exploring considering. and meatsuring, and comparing the informution thought lime dnaving until I had grasped and wenderstood filly what each had to contribute in sems of ingensity or skills this is bow my passion and delight in learning nelinved the labor of writing. Yes to collate material from

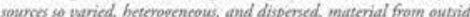
the normal muge and skill of any writer, to review it in dignified manmer, to arrange in a proper order, to articulate previsely and explain nattionally, surety all this required an ability and learning grater than l would profers to have

L. B. Alberti, On the Art of Brillding in Ten Books, Book VI. Chapter 1.

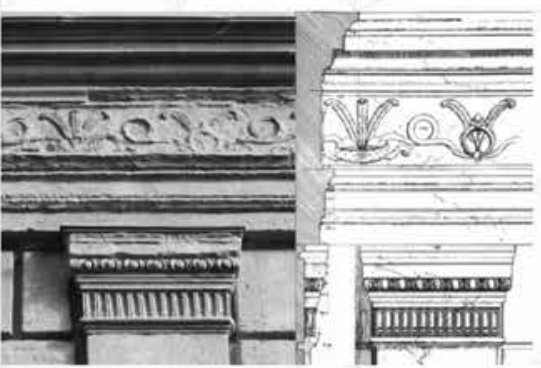

Figuna to

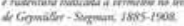

Figure 70

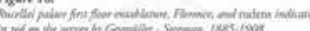

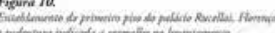

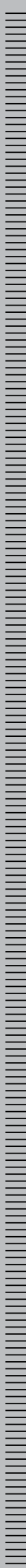

\section{Molduras do Ornato}

Com a gmapa de Deus, agnadand intecralar aqui umes poucas coisas As molduras do ornato sado ettas: a faica, o ressalto, a rudentura. o cordao, o catveto, a gola, a onda. Toda a molduna i um delineamento

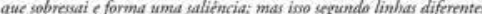
Com efcito, o delineamento da fraiva imira a letra Li a faixa ce mormo que o filete, mas mais langa. O ressal to e usma faixa muito saliente. Hesire se nio devia chamar hera d̀ mudentura: nat verdade adere d. medida que se estende; co delineasmento da sua saliència é como a letna Cligada a soguir à letnt $L$ assim $\}$, Eo condia ó uma rudentura

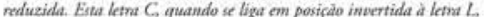
assim $\zeta$, formand um caveto. Mas se se ligar am $S$ a seguir à letra $L$, asim 4 , chamarse gola: pois imita a gola de um homem. Ss, porim a seguir à letnat $L$ se acrocenta um $S$ deitado e em posipäo inarrida. assim $\zeta$, chamarusend onda, devido dे semelham far da inflexio.

L. B. Alberti, Da Arte Edificatória, Livro VH, Cap. 7.

\section{Particulae Ornamentorum}

Here I might make a brief dignession. for the sake of alarify The following arr the minor molding of ornamental wark. platband, corona, onolo, atnagath chameh wave, and gulles. All of dhem project, but aach has a different outline: The platbiand bas a lineament like the letter $L_{;}$it is similar to she filles, only wider. The conona is a particularty prominent platband. The ovolo 1 usts almest tempted to call ivg berituse it extends and clings: its lineament is like the letter $C$ surmounted by letter $L$. like so: 4 . The astragal is a litrle ovolo. The letter $C$. if noversed and surmounted by the letter $L$. like so, $L$ produce at channel. But if the letter $S$ is sommenuted by tbe letter $L$, like so.

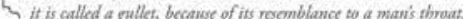
If howrver, beloup the letter $L$ an imerted $S$ is attadived, like so.

$\zeta$ it is cotled a wave, because of its similar curve.

L. B. Alberti, On the Art of Building in Ten Books, Book VII. Chapter 7. 


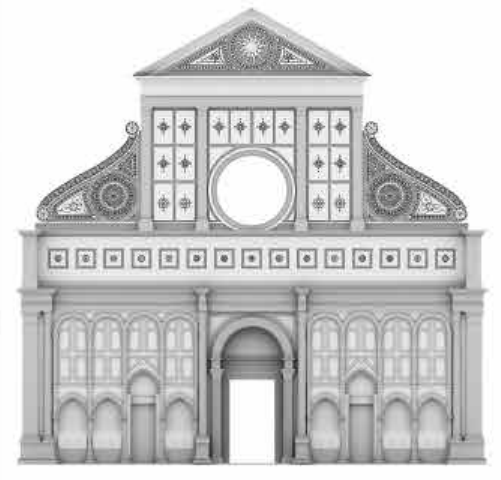

Figunat 11.

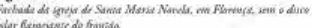

Figure ts.

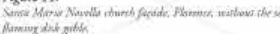

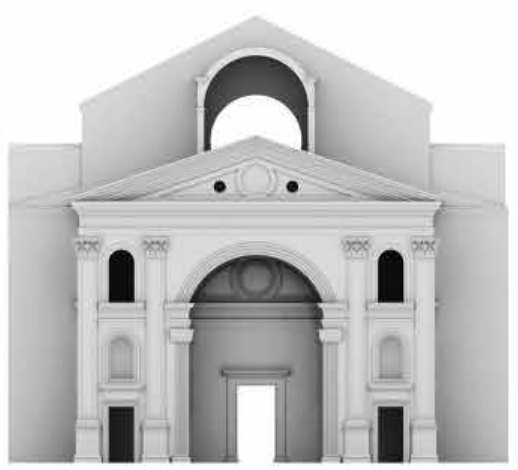

Figuna 12.

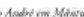

Figue 12 .

\section{Variedade}

Mas, neste dominio, deve-se ter em conta aquila que em todas as partes de um edificio merece ser forsemense criticado. se faltar. bem como aquilo que, se etiver presente, the confere graca e comodidade: isto \&, que haja uma cerra sariedade tanto de angulos. cono de linhas, e ainda de cada uma das partes,

de modo a náo ser nem demasiado frequente, nem totalmente nara, mas disposta em funçáo da utilidade e da graţa, de tal modo que partes inseiras correspondem a partes inteiras, e partes iguais a partes iguaic.

L B. Alberri, Da Arte Edificatória, Livro I, Cap. 8.

\section{Varietas}

As we deal with these matten, there is something we must watch. since we would be strongly criticized for its absence in any part of the building, while its prosence contributes much to charm and convenience. I mean that censain variety posseved by both angles and titues, as well as by individual pares, which is neicher too much nor soo lintle, but so disposed in terms of use and grace. that whole may correspond to whole, and equal to equal.

L. B. Alberti. On the Art of Building in Ten Books, Book 1, Chapter 8.

\section{O Arquitecto Prudente}

Por conseguinte, ume arguitecto prudente procederd da forma seguinte (...) Em suma, definind tudo: nada deixard a que näo prescreva como que a sua lei e a sua medida. Quase todos etes aspectos. embora parega que dizem respeito à solidez e ao uso, acima de tudo, todavia têm tal importancia por si mesmas gue, se forem menosprezadas, arnastario consigo um enorme defeito de deformidade.

L. B. Alberti, Da Ante Edificatória, Livro IX, Cap. 9

\section{Bene Consultus}

A prudens man would act like this. (...) In short, he wonld set out avrything and leate nothing without some precautions seems to be structur and we, they are alsoss all such that if ignored they will lead to considenable deformities.

L. B. Alberti, On the Ars of Building in Ten Books, Book IX, Chapter 9 . 


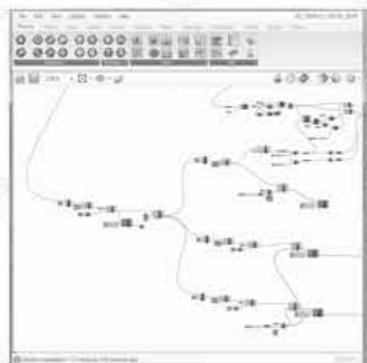

Figurat 1.

Figere l.

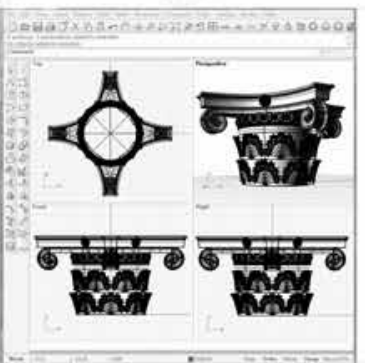

Fogun 2

Figerr 2

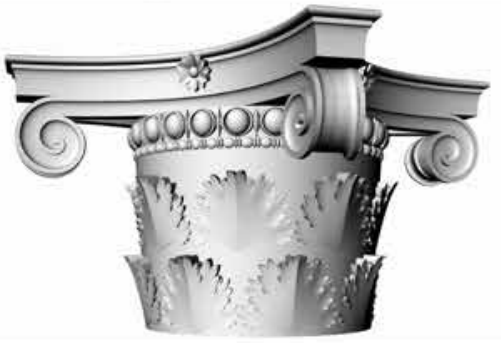

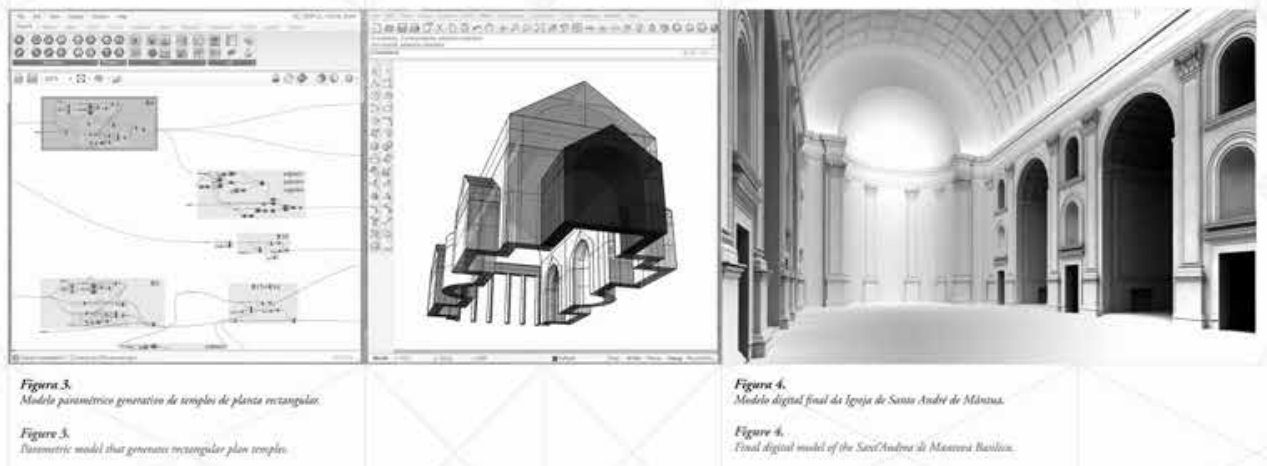

\section{Modelaçáo paramétrica}

A codificaçâo do tratado em gramáticas da forma permite a geraçáo exacta de sistemas de coluna e de edificios de acordo com as regras estabelecidas por Alberti. A implementação das gramáticas em modelos paramétricos torna essa geraçáo mais eficiente, e permite uma exploraçáo interactiva do espaço de soluçóes definidas pelo tratado.

Estes modelos paramétricos foram implementados em Grasshopper, um interface de programaçáo visual que interage com o software de modelaçáo Rhinoceros, de modo a gerar modelos digitais tridimensionais de acordo com as instruçóes de Alberti.

Os resultados dependem da variaçáo de parâmetros, correspondendo ao que o autor prescreve para o número e proporçáo dos vários elementos. Por defeito, os parâmetros implementados são os prescritos por Alberti.

No entanto, estes podem ser facilmente alterados, de modo a gerar modelos náo-canónicos.

\section{Parametric modelling}

The codification of the treatise into shape grammars enables the completc generation of columns systems and buildings according to the rules established by Alberti. The implementation of the grammars into paramerric models makes such a generation more efficient and enables the interactive exploration of the space of design solutions defined by the treatise.

These parametric models were implemented in Grasshopper, a visual programming interface that interacts with modelling software Rhinoceros, and generate three-dimensional digital models according to Alberti's instructions. The outpur depends on the variation of parameters, which correspond to what the author prescribes for the number and proportions of the various dements. By default, the parameters implemented in the Grasshopper model are the ones prescribed by Alberti. However, these parameters can exsily be altered, hence generating non-canonical models. 


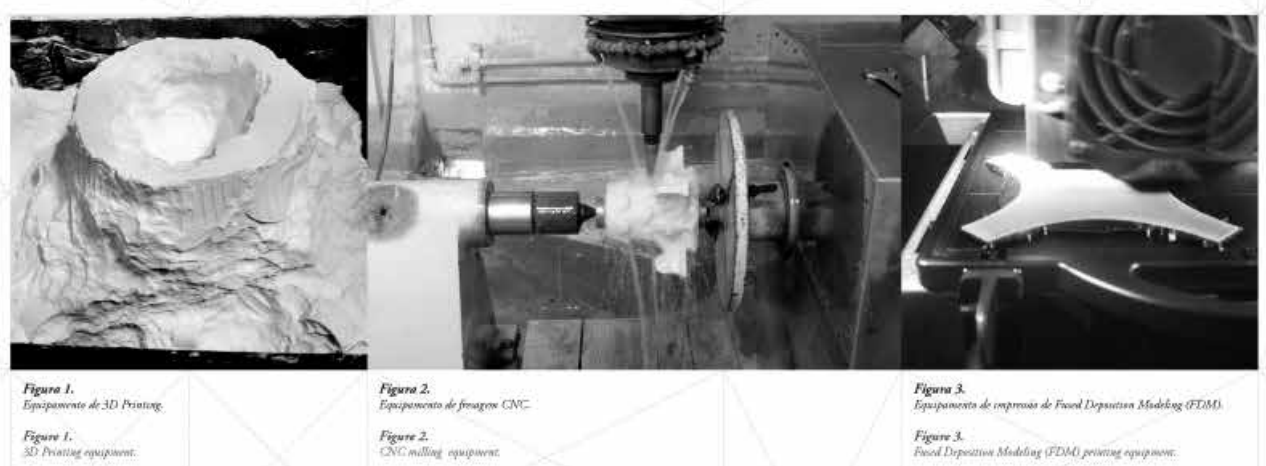

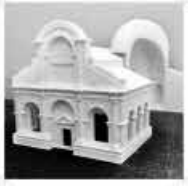

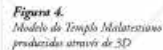

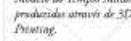

\section{Figure 4.}

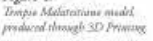

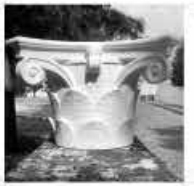

$$
\text { Figunt 5. }
$$

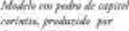

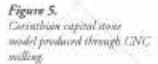

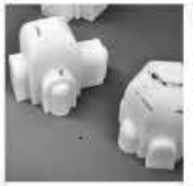

Figure 6.

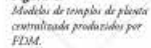

Figure 6 .

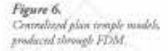

\section{Prototipagem rápida}

O termo 'prototipagem rápida' é usado para descrever tecnologias em que protótipos são produzidos rapidamente utilizando técnicas automáticas, incluindo a deposiçáo automática de camadas de material, fresagem $\mathrm{CNC}$ ou corte a laser. $\mathrm{A}$ adequabilidade de cada uma das técnicas depende de factores como, por exemplo, a escala ou complexidade formal do modelo a ser produzido.

Com a prototipagem rápida é possivel produzir protótipos físicos a partir dos modelos digitais gerados pelos modelos paramétricos, permitindo estudar e ilustrar as qualidades formais e espaciais da interpretação de Alberti da arquitectura clássica.

As conclusôes retiradas da produçâo de objectos através de prototipagem rápida podem contribuir para o melhoramento dos modelos paramétricos, dando informaçáo sobre possíveis fragilidades e inconsistências. Assim, esta informação é reintroduzida no processo geral.

\section{Rapid prototyping}

The term 'rapid prototyping' is used to describe technologies in which prototypes are produced quickly with any automated rechnique, including by the auromated deposition of tayers of material, CNC rouring or laser curring. The suitability of each technique depends on factors such as scale and formal complexity of the model being produced.

With rapid prototyping we can produce physical prototypes from the digital models generated by the paramerric models, allowing to study and illustrate the spatial and formal qualities of Alberti's interpretation of classical architecture.

Conclusions derived from the production of objects through rapid prototyping can help imptoving the parametric models, providing information about possible frailties or inconsistencies. Therefore, this information is fed back into the whole process. 


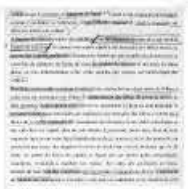

Figura l.

Figwe 1 .

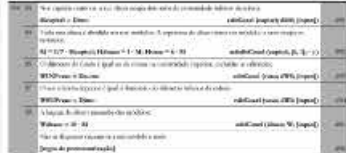

Figure 2.

Figure 2 .

Fogure 2.

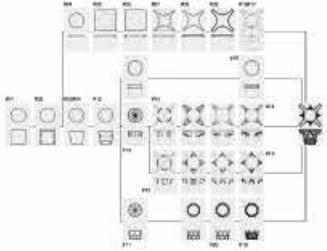

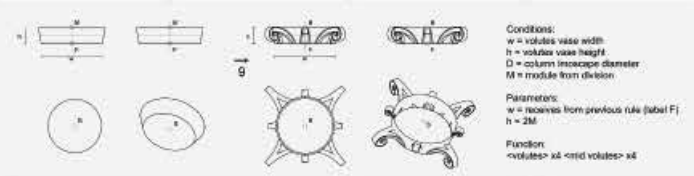

\section{Figured}

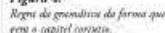

Figured.

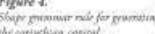

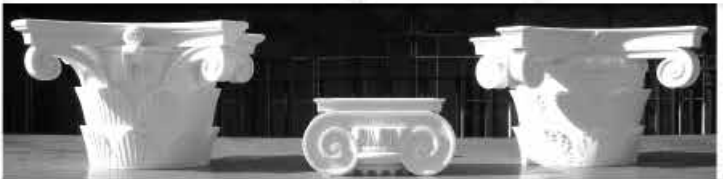

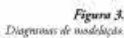

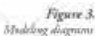

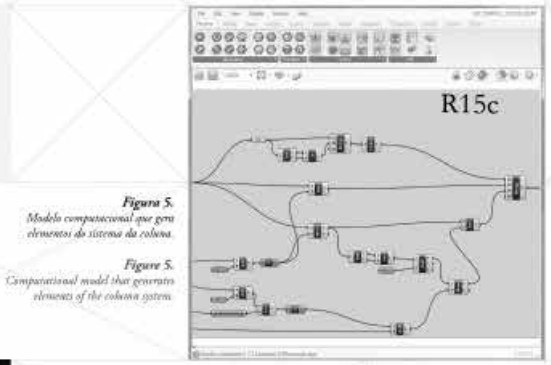

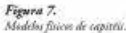

Fipun 7.

\section{Abordagem metodológica}

$\mathrm{O}$ tratado de Alberti pode ser pensado como um conjunto de algoritmos que explicam como criar edificios de acordo com os cânones da arquitectura clássica. Assim, a metodologia do projecto passa por uma análise sistemática do tratado (figura 1), permitindo traduzir os algoritmos nele descritos sucessivamente em esquemas (figura 2) e diagramas (figura 3) e, em seguida, numa gramática de forma (figura 4), ganhando assim uma compreensâo profunda da estrutura formal da interpretaçáo Albertiana da arquitectura clássica. A gramática de forma é depois convertida num modelo paramétrico implementado num programa de computador (figura 5), ou seja, num modelo computacional. Concretamente, a gramática foi convertida num modelo paramétrico implementado em Grasshopper, uma linguagem de programaçâo visual. Este programa é entáo usado para gerar modelos digitais tridimensionais (figura 6), traduzíveis em desenhos bidimensionais, ou modelos de realidade virtual, ou ainda em modelos físicos (figura 7), através de técnicas de prototipagem rápida.

\section{Methodological approach}

Alberti's treatise can be considered to be a set of algorithms that explain how to design buildings according to the canons of classical architecture. Thus, the projoct's merhodology stares by a systemaric analysis of the treatise (figure 1), enabling to translate the described algorithms into schemes (figure 2) and diagrams (figure 3). and then into a shape grammar (figure 4), providing a deeper understanding of the formal structure of Alberti's inrerpretation of classical architecture. This grammar is then converted into a parametric model implemented into a computer program (figure 5), that is to say, into a computational model. Namely, the grammar was converted into a parametric model implemented in Grasshopper, a visual programming language. This program is then used to generate three-dimensional digital models (figure 6), that can be translated into two-dimensional drawings, or into virtual reality modek, or into physical models (figure 7), through rapid prototyping techniques. 


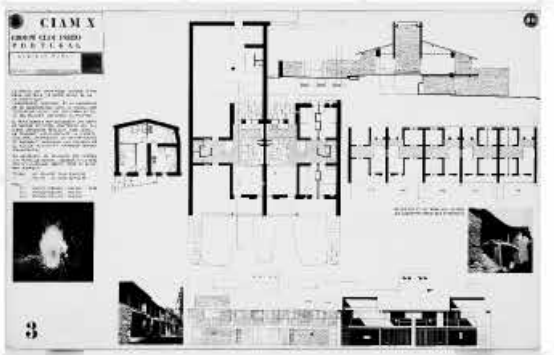

Welfare Homanism

o arquitecto, para realizar-se tem de saber fazer e, ao mesno tempo. conhecer as coisas, e os homens, e o mundo, ea vida."

O. L. Filgueinas, 1985, p. 16

Welfare Hunanism

Whe architect to be accomplished, mast know how to do and, at she same time, know about things, man, the world and life."
Habitat Rural

"Cremos que todo o homem, e näo somente es arquitectos $c$ es urbanistas, tem o dirvito e o darer de participar e de colabonar (comunhaso) na criapão e no desentolvimento do sen habitat" CIAM Porto, Dubromik, 1956

Native Genitus

"We believe every man, and not jest she architects and urban plannens, Was the rigit and the ducty to participate and callaborate (communion) an the cration and development of his habitat."

Figuma // Figure 1 .

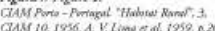

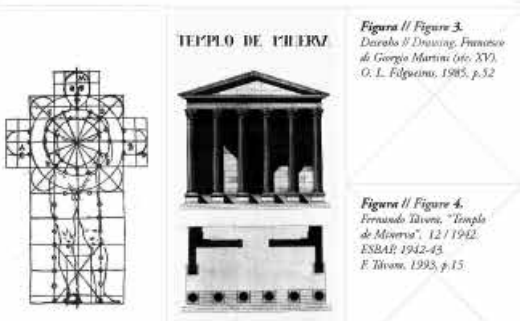

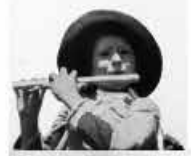

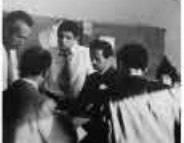

Figura II Figure 2.

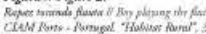
CUM IR 1956

Figura // Figure 5. Corat Ramos

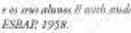

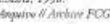

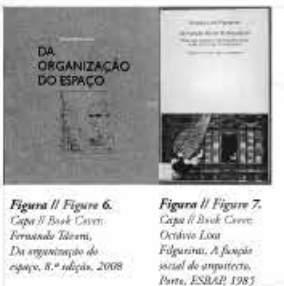

Educąạo Colectiva

Anquitectos, pintores cescultores exigem, ainda dentro das Escolas. de uma educapáo colectiva e de som sentido de colaboraça totalmente diferente daquele que até este momento só tèm contribuido para os afastar."

C. Ramos, 1935

Colective Education

"Anchiects, painters, and sculptors demand, a collective educcasion yet wishin the schools, and a totally different sonse of collaboration from that which has only contributed to zake shem apart hitherte"

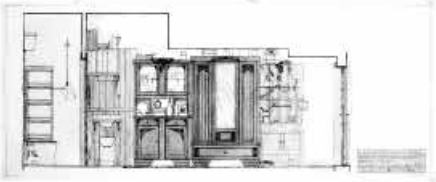

Fizum II Figure \&.

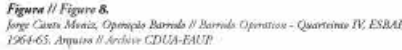

\section{Arquitectura para um Humanismo Moderno Do ensino à prática}

Não acometas nada que seja superior às forças humanas, nem empreendas coisa alguma que de imediato entre em conflito com a natureza.

\section{B. Alberti, Da Arte Edificatória, Livro II, Cap. 2.}

A partir de uma reflexáo sobre a ideia de educaçáo colectiva aplicada por Carlos Ramos na Escola do Porto, e de uma análise ao projecto do grupo CIAM-Portugal para um Habitat Rural, esta investigaçáo procura estabelecer uma revisấo crítica do impacto do trabalho de Alberti e do humanismo renascentista no desenvolvimento de um novo humanismo social, que reconhece a importância da abordagem platónica, procurando, no entanto, um maior empenhamento social. Este tema é desenvolvido em duas linhas de investigaçáo:

Humanismo e Educaçáo Moderna: a Escola de Carlos Ramos; O Vernacular e a Modernidade: Em prol de um habitat humanista.

\section{Architecture for a Modern Humanism} From education to practice Nothing should be attempted that lies beyond human capacity nor anything undertaken that might immediately come into conflict with Nature. L. B. Alberti, On the Art of Building in Ten Books, Book II, Chapter 2.

From a reflection on the idea of collecrive education applied by Carlos Ramos in the Porto School, and an analysis to the project for a Rural Habitat designed by the group ClAM-Portugal, this research aims at critically reviewing the impact of Alberti's work and the Renaissance humanism on a new, emergent "welfare" humanism, which acknowledges the importance of a platonic approach but is driven to foster a more socially engaged one. This topic is developed in two research lines:

Humanism and Modern Education: the School of Carlos Ramos: Vernacular and Modernity: In praise of a humanist habitat 

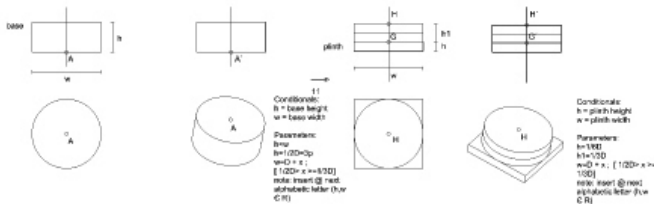

The measurements of all the parts are taken from the diameter at the base of the column, according to the rule first established by the Dorians. Theymade the height of the base half the diameter. The width of the die in eitherdimension would be no more than one and a half and no less than one and athird times that diameter. The height of the base was then divided into threeparts, one of which was taken up by the thicknes of the die.
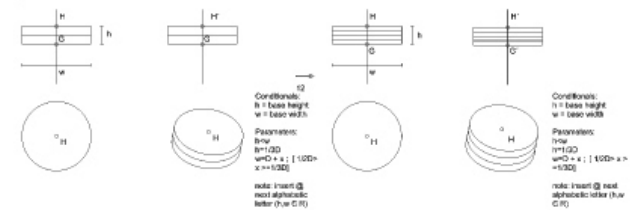

The thickness of the remainder of the base, excluding the die, was then divided into quarters,
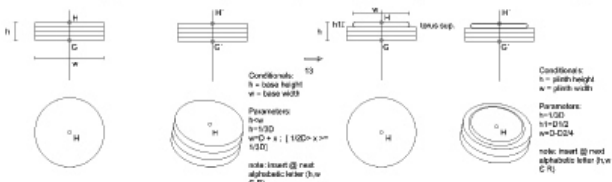

the top one being taken up by the upper torus.

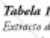

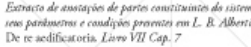

Table I.

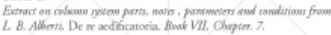

\section{Gramática da forma da Sistematização da coluna da Da Arte Edificatória}

A gramática da forma da sistematizaçâo da coluna, enquadrada nas gramáticas descritivas (Stiny, 1981) e gramáticas da forma (Stiny e Gips, 1972) e com corpus o texto do tratado de Alberti (Santo and Kruger, 2011) e os seus edifícios, é testada na gramática de alguns edifícios Portugueses verificando a influência do tratado nessas construçốes através das transformaçōes verificadas nas regras (Knight, 1983) . Cada regra da gramática da forma contem a passagem correspondente do texto, condiçôes e parâmetros e um conjunto de rótulos.

Exitem 2 estilos de Bases: Dórico e Jónico. Neste caso apresenta-se as regras iniciais para gerar uma Base Dórica e a sua derivaçáo. Ao contrário da Base Jónica que contem 2 variaçōes a Base Dórica varia parametricamente no seu Plinto.
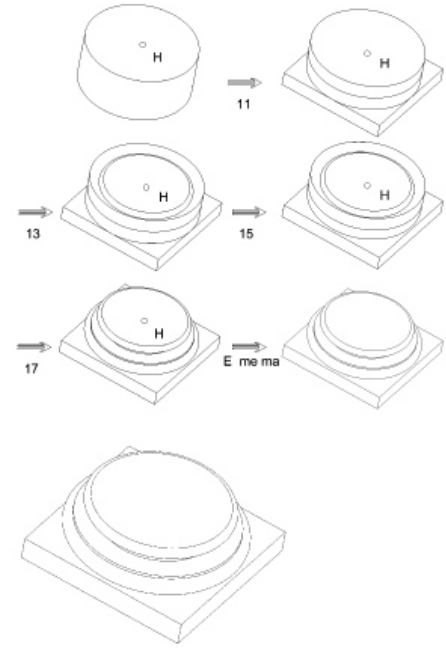

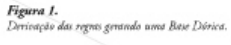

Figure 1 .

De re aedificatoria systematization of column's shape grammar

The systematization of column's shape grammar has a computational framework provided by description grammars (Stiny, 1981) and shape grammars (Stiny and Gips. 1972), as well as the corpus of Alberti's treatise (Santo and Kruger, 2011) and his buildings and is applied in order to test the grammar of some Portuguese buildings to detect evidence of Alberti's influence and the rules transformations verified (Knight, 1983). The grammar is made by a set of rules where has it is indicated the reference to Alberti's treatise, its conditions and parameters and a ser of labels. The initial rules to generate a Doric Base and is derivation are showen. The Iónic Base as 2 variations and the Dóric has paramétric variations in its plinth. 


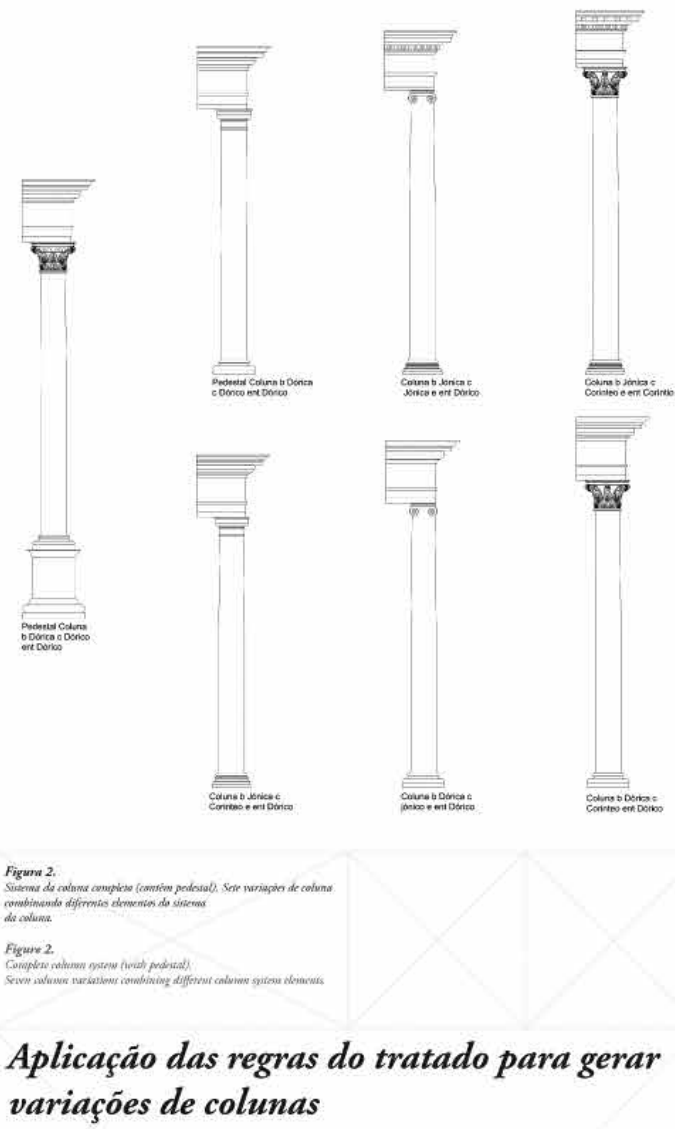

A gramática da sistematizaçáo da coluna é constituida por um vocabulário mínimo de três letras $\mathrm{L}, \mathrm{C}$ e S com as variaçóes de $C$ invertido e $S$ invertido e as variantes paramétricas da letra $L$. Estas letras combinadas prefazem as molduras Rudentura, Caveto, Gola e Onda que são aplicadas aos diferentes elementos do sistema da coluna: Pedestal, Base, Coluna (Fuste), Capitel e Entablamento. Estes podem ser apresentados em combinaçóes dos estilos Dórico, Jónico, Coríntio e Compósito. Estas combinaçōes de elementos discretos podem gerar cerca de 458 colunas diferentes.

A coluna (ou fuste) pode ser lisa, com 20 ou 24 caneluras

com ou sem rudentura. Com e sem filete. Pode ser Salomonica.

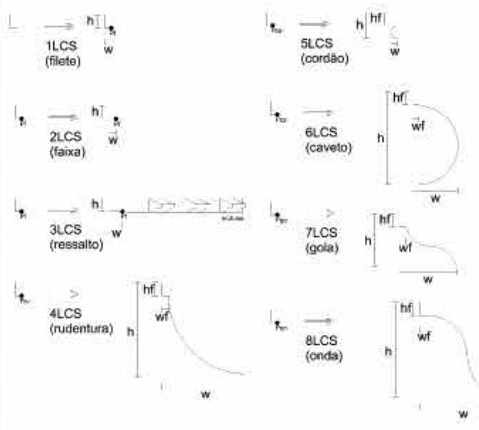

Tabela 2

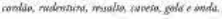

Table 2

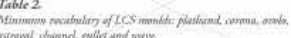

Generating variations with the treatise rules

The Column Systematization grammar has a minimum vocabulary of L, C, S and an inverted C and S with letter L parametric variations that gave the molds Ovolo, Channel, Wave and Gulens. The combination of these molds gives different column system elements: Pedesral, Base, Column (Shaft), Capital and Entablature. They might be connected with differen

combinations of Doric, Ionic, Corinthian and Composite scyles. The combinations of those discreet elements may produce around 458 different columns.

The column (or Shaft) may be plain, with 20 or 24 channels and rudens. With or without fillet. May be Salomonic. 

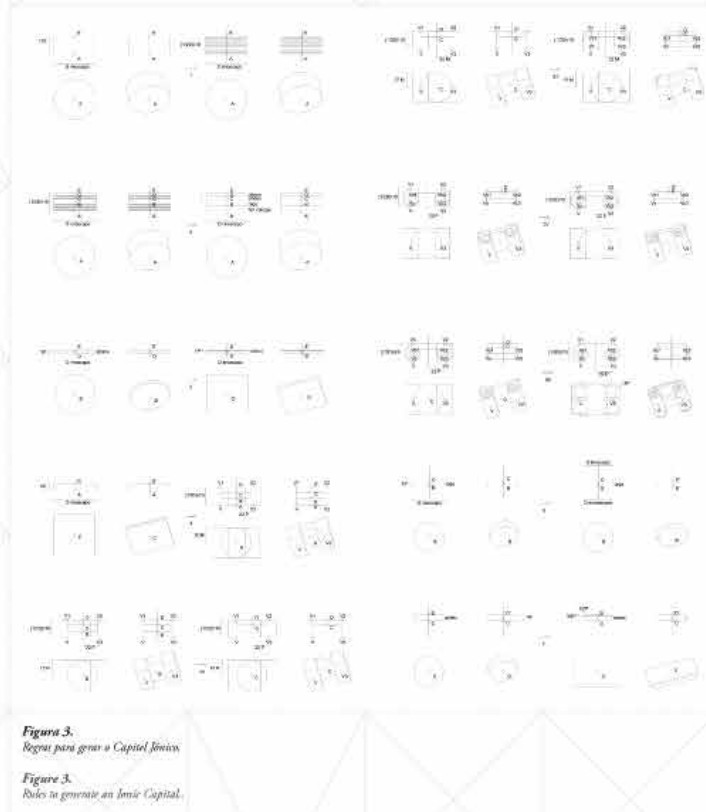

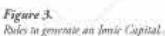

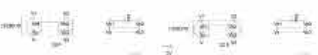

$\frac{ \pm}{ \pm} \div$

$\because-\because+-+$

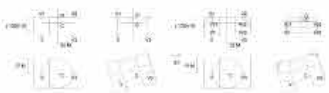

i.

$\vec{x}$

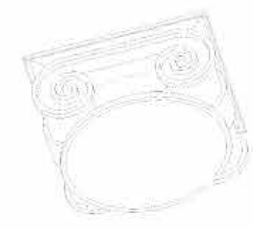

Figran f.

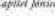

Figures.

\section{Conjunto das regras do Capitel Jónico e sua derivação}

Existem capiteis em 4 estilos diferentes. O Dórico, o Jónico, o Coríntio e o Compósito. O capitel Dórico contem 2 variaçóes. O capitel Compósito diverge do capitel Coríntio variando deste nas suas volutas e caulículos e na aplicaçáo do cortex. Neste caso sáo apresentados um conjunto de regras e a derivaçáo detalhada de um Capitel Jónico. Alberti náo descreve a constituiçáo do capitel (assim como todos os outros elementos com exepçáo do Entablamento) de forma sequencial nem como uma sucessiva adição de elementos. Inicia a descriçáo usando um elemento genérico, subdividindo-o em partes evocando-as posteriormente em momentos diferenciados do texto detalhando-as com as molduras.

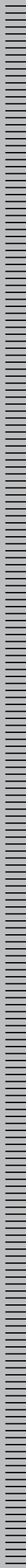

\section{Ionic Capital set of rules and its derivation}

There are 4 different styles of capitals: Doric, Ionic, Corinthian and Composite. the Doric Capital has 2 variations. The Composite diverges from the Corithian in irs Volutes, Cauliculi and Cortex. In this case a set of rules and ies derivation of a lonic capital is showen. Alberti does not describe the Capital (and all other elements excepring the Entablature) in a sequential way or as an addition of elements. He starts the description subdividing a generic element in parts, then detailing those parts in different moments of the text using the moulds. 

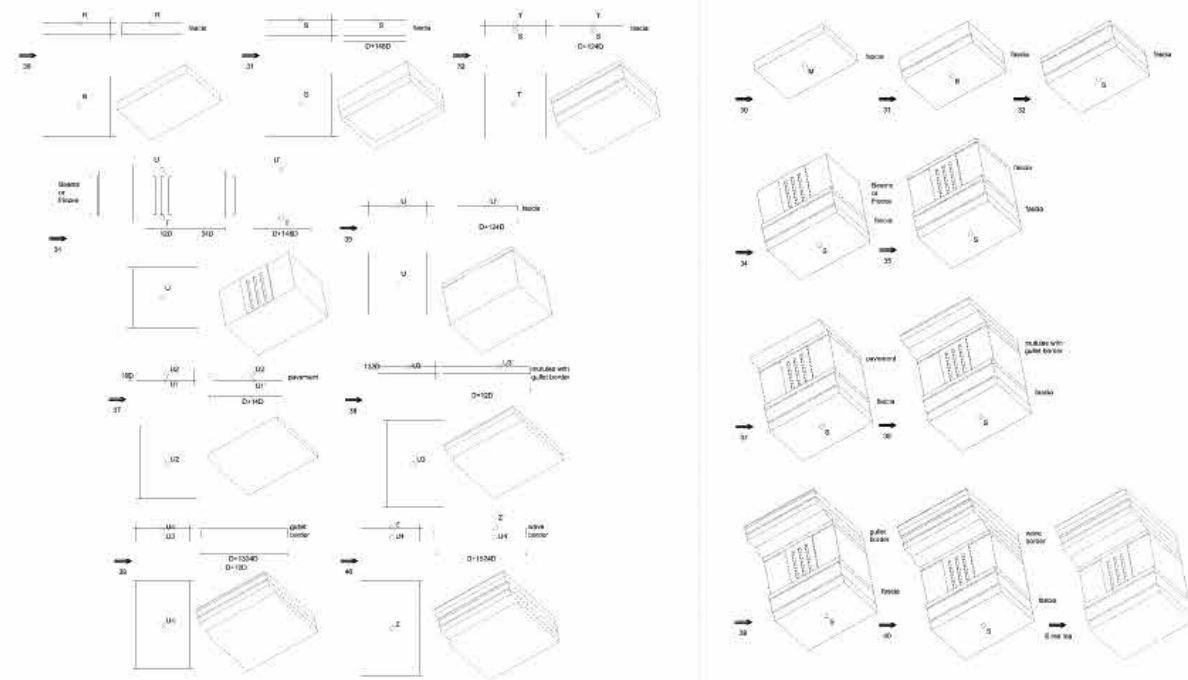

Figura 5.

Figara 6.

Figures.

Dorine

Figure 6

E

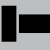

\section{Conjunto das regras de Entablamento Dórico e sua derivaçáo}

Há 3 estilos de Entablamento. O Dórico, o Jónico e o Coríntio, sendo este dois ultimos constituidos pelos mesmos elementos variando somente na adiçáo de Ovulos e Mútulos por cima dos Denticulos. Um Entablamento é constituido por três partes destintas: A arquitrave, os Frizos e a Cornija. Cada uma destas partes é, por sua vez, formada por três ou quatro outras partes que por sua vez sấo subdivididas e assim sucessivamente. Alberti descreve o Entablamento de modo diferente do resto dos elementos do sistema da coluna, sendo neste caso uma descriçâo Baixo-Cima da adiçăo de molduras.

\section{Doric column Entablature shape grammar and derivation}

The Entablature has 3 different styles. Dóric, lónic and Corinthian. This last two styles have the same elements but are added Eggs and Mutules on the top of the Dentil. A entablature has 3 parts: Architrave, Frize and Cornice. Each of these parts is formed by three smaller parts, which in turn are formed by other smaller parts, and so on. However, Alberri describes the Entablature and the rest of the column system in different ways, The Enrablature is described in a bottom-up fashion by the successive addition of monlds. 


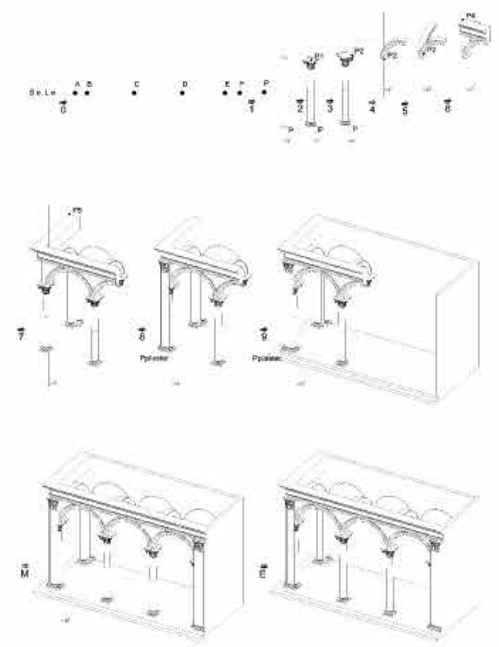

Figura 7.

Figure 7 .
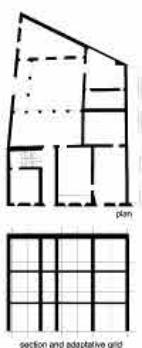

Figura \&

Figure 8.

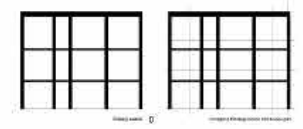

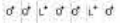

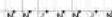

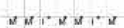

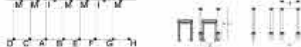

(

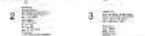

$\cdots \quad \cdots \cdots$

. n w

ilir ijir:

L.

4.

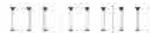

$\therefore+\cdots=$

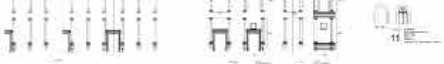

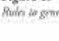

\section{Generation of Loggia and Rucellai Palace shape grammar}

This poster shows the rules needed to generate a colonnade of the Loggia Rucellai (1466) and the Rucellai Palace façade (started 1461) in Florence using Doric, Ionic and Corinthian grammars in order to construct a grammar from Albert's treatise. utilizada na Loggia Rucellai (1466) e na fachada do Palácio Rucellai em Florença (com inicio em 1461) projectado por Alberti, onde sâo usadas as gramáticas da forma do sistema da coluna com elementos Dóricos, Jónicos e Coríntios. Estas gramáticas paralelas foram desenvolvidas em quatro vistas: planta, corte, alçado e axonometria. 

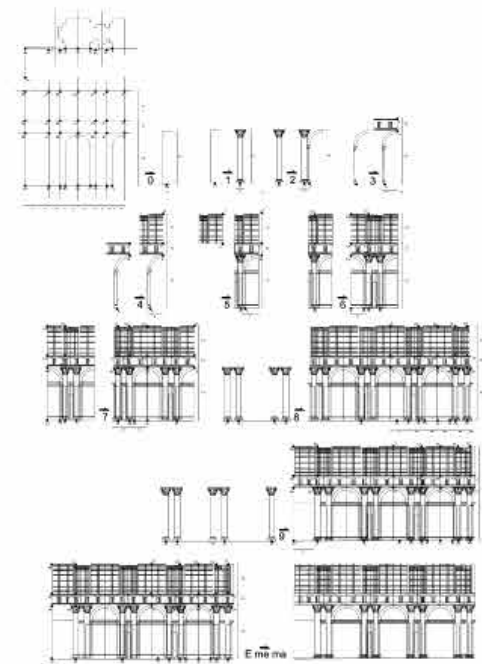

Figund 9.

Figure 9.

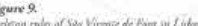
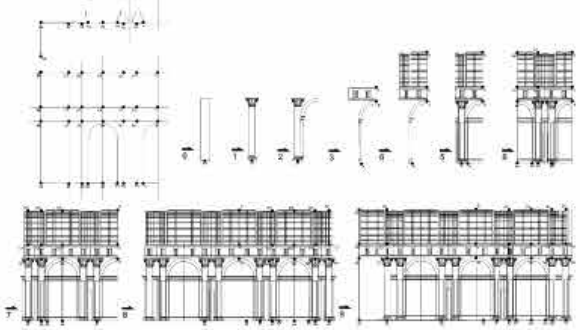

Emema ।

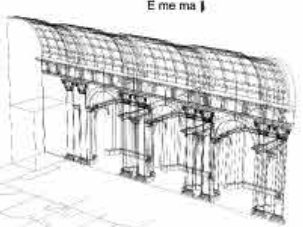

Figurst to.

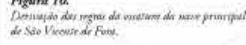

Fizour 10.

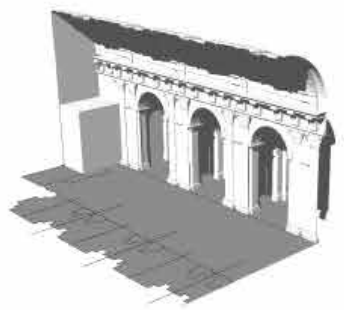

Gramática da forma para a geração da Ossatura da nave principal de Sáo Vicente de Fora

Sáo Vicente de Fora em Lisboa foi renovada no século 16 cerca de 1583. A secçáo da igreja em estudo é composta por uma nave principal com aboboda de berço e tres capelas intercomunicantes de cada lado. Sáo notáveis as semelhanças estruturais com Sant 'Andrea em Mantua sobretudo a aplicaçáo da ossatura e elementos do sistema da coluna.
São Vicente de Fora main nave skeleton (ossatura) shape grammar.

Såo Vicente de Fora in Lisbon has is renovation starred in the end of the 16 th century circa 1582 . It has is main nave wirh vault cradle and 3 chapels interconnected, It is nororious its similarities with Alberti's Sant Andreas in Manrua in the structure of the building and in the use of certain proportions of its skeleton (ossarura) of the column system. 


\begin{tabular}{|c|c|c|}
\hline Rarres dos Templos W Temple Parus & Parimetrool Parameters & 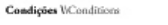 \\
\hline 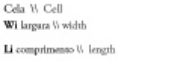 & $L i=\alpha \mathbf{w}$ & 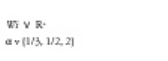 \\
\hline 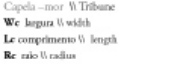 & $\begin{array}{l}w_{k}-\alpha^{\prime} w_{n} \\
k_{k}=w_{k} \\
k=w_{k}\end{array}$ & $\alpha \times[2 / i, 46\} \mid$ \\
\hline 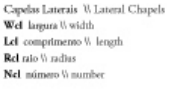 & $\begin{array}{l}W_{d-\varphi}=W_{t} \\
L d-y_{t} W_{t} \\
R S=y_{2} W_{t}\end{array}$ & 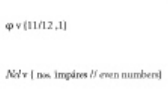 \\
\hline 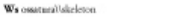 & $w_{s}-\phi w d$ & $1 / 3 \leqslant \phi^{\prime} \leq 1 / 3 \vee 0<-1 / 2$ \\
\hline
\end{tabular}

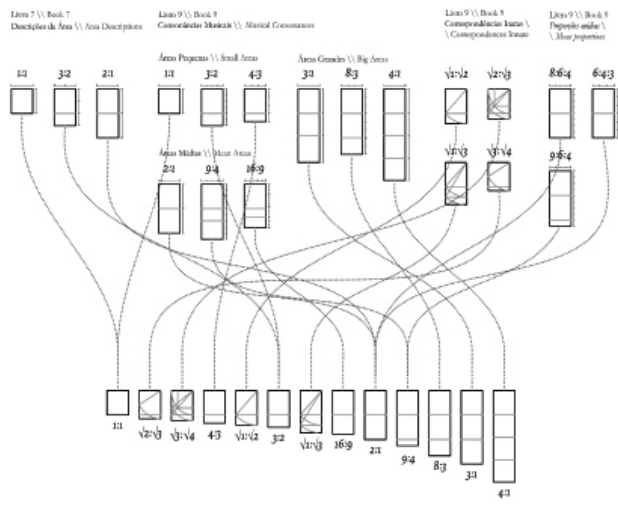

Tabelal.

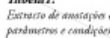

Table L.

Figuna 1.

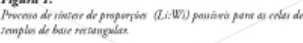

Figure 1 .

\section{A leitura do De re aedificatoria Gramática da forma de Edificios Sagrados}

O tratado expressa em termos algorítmicos o conhecimento geral para o projecto de edifícios sagrados - templos. Estas descriçóes são maioritariamente feitas nos Capítulos IV e V do Livro 7 "O Ornamento de Edificios Sagrados". O processo de definiçáo da gramática da forma iniciou-se pela traduçáo de descriçóes textuais em parâmetros e condiçốes dos componentes aquitectónicos dos templos.

Em quase todos os templos quadrangulares, os Antigos tiveram em vista produzir uma área tal que o comprimento fosse uma vez e meia a sua largura; outros construiram-ne tal que a largura fosse superada em um terço pelo comprimento; outros quiseram que o comprimento tivesse o dobro da largura. Nas áreas quadrangulares o maior defeito de deformidade é se bouver algum ângulo que náo seja recto.

In De re aedificatoria, Livro 7 . IV p.2.

Neste excerto, Alberti inicia a descriçâo das características formais das celas dos edifícios sagrados . A tabela 1 sintetiza o conhecimento inferido sobre as proporçōes dos templos e das respectivas capelas, pela definiçấo dos seus parâmetros e condiçốes lógicas.

\section{Reading De re aedificatoria \\ Sacred Buildings Shape Grammar}

The treatise expresses in algorithmic terms the knowledge base for the design of sacred buildings - temples.

That knowledge is mainly described on the Chapters IV and V of Book 7 "Ornament to Sacred Buildings", Chapters V and VI of Book IX "Ornament on Private Buildings", from the

De Re Aedificatoria. The process of defining the grammar of form began by translating textual descriptions on parameters and conditions the temples archirectonical components.

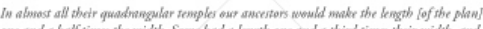

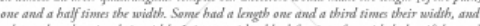

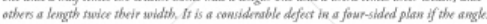

In this excerpt, Alberti begins the description of the formal characteristics of the cells of sacred buildings. Table 1 summarizes the inferred knowledge about the proportions of the temples and respective chapels, the definition of its parameters and logical conditions. 


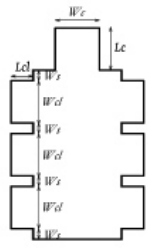

paraimetros $\backslash \backslash$ parameter

Ic largura da capela-mor \\main chapel width

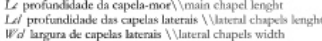

Vod largura de capelas intenis Materal chapels width

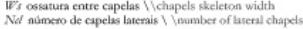

condipoies thounditions

$s=(L j \cdot \mathrm{N} d(\mathrm{~W} d) / \mathrm{N} d+1)$

$1 / 3 \leq \psi^{\prime} \leq 1 / 3 \vee \psi^{\prime}=1 / 2 \vee \vee(\sqrt{2} / \sqrt{1}, \sqrt{3} / \sqrt{2}, \sqrt{3} / \sqrt{1}, \sqrt{4} / \sqrt{3}\}$

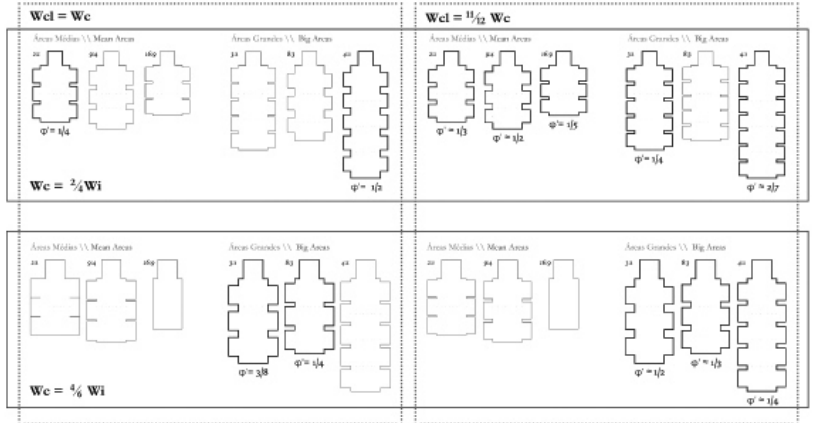

Figura 2.

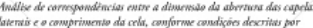

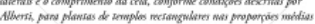

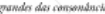

Figure 2.

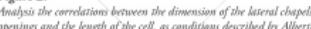

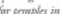

\section{Esquemas Paramétricos}

\section{Gramática da forma de Edifícios Sagrados}

O desenvolvimento de esquemas paramétricos foi usado como metodologia para a sistematização de um conjunto de relaçóes algorítmicas que informam as formas e proporçóes de cada uma das partes do templo.

Nos Capítulos V e VI do Livro 9 - Ornamento de Edifícios Privados, Alberti descreve um conjunto de sistemas de proporçóes para a definiçấo da geometria base dos edifícios - consonâncias musicais, correspondências inatas e medianas. Estas proporçóes ampliam o conjunto proporçóes inicialmente considerado no Livro para a definiçấo das proporçóes da cela. A Figura 1, exemplifica o processo de síntese de relaçôes paramétricas que determinam a Regral, considerando a totalidade de situaçốes previstas em ambos os livros. Para a definição morfológica dos templos importa considerar a adição da capela-mor e das capelas laterais. As Figuras 2,3 e 4, mostram partes do processo de sistematizaçáo do conhecimento relativo a estas operaçóes, resultando num esquema paramétrico e relaçốes espaciais.

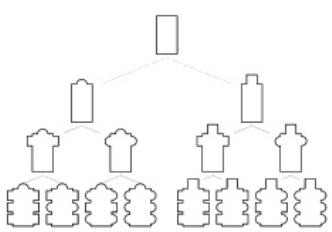

igura 3

Figure 3.

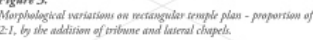

\section{Parametric Schemas}

Sacred Buildings Shape Grammar

The development of parametric schemas was used as a methodology for systematizing a set of algorithmic relations that inform the shape and proportions from each part of the temple.

In the Chapters V and VI of Book IX - Ornament on Private Buildings, Alberti describes a set of proportional principles to define the temples outlines - musical consonances, correspondentiae inatae and arithmetic means. These proportions amplifies the initial ones described in Book VII to determine the cell proportions.

Figure 1, exemplifies the process of synthesizing parametric relations to determine Rule 1, considering the overall situations presented in both books.

Also important to define the temples morphology are the addition of tribune and lateral chapels to the cell outline. Figures 2, 3 and 4 shows the parametric relations encoded and process of systematizing the knowledge on those parts of the temples. 

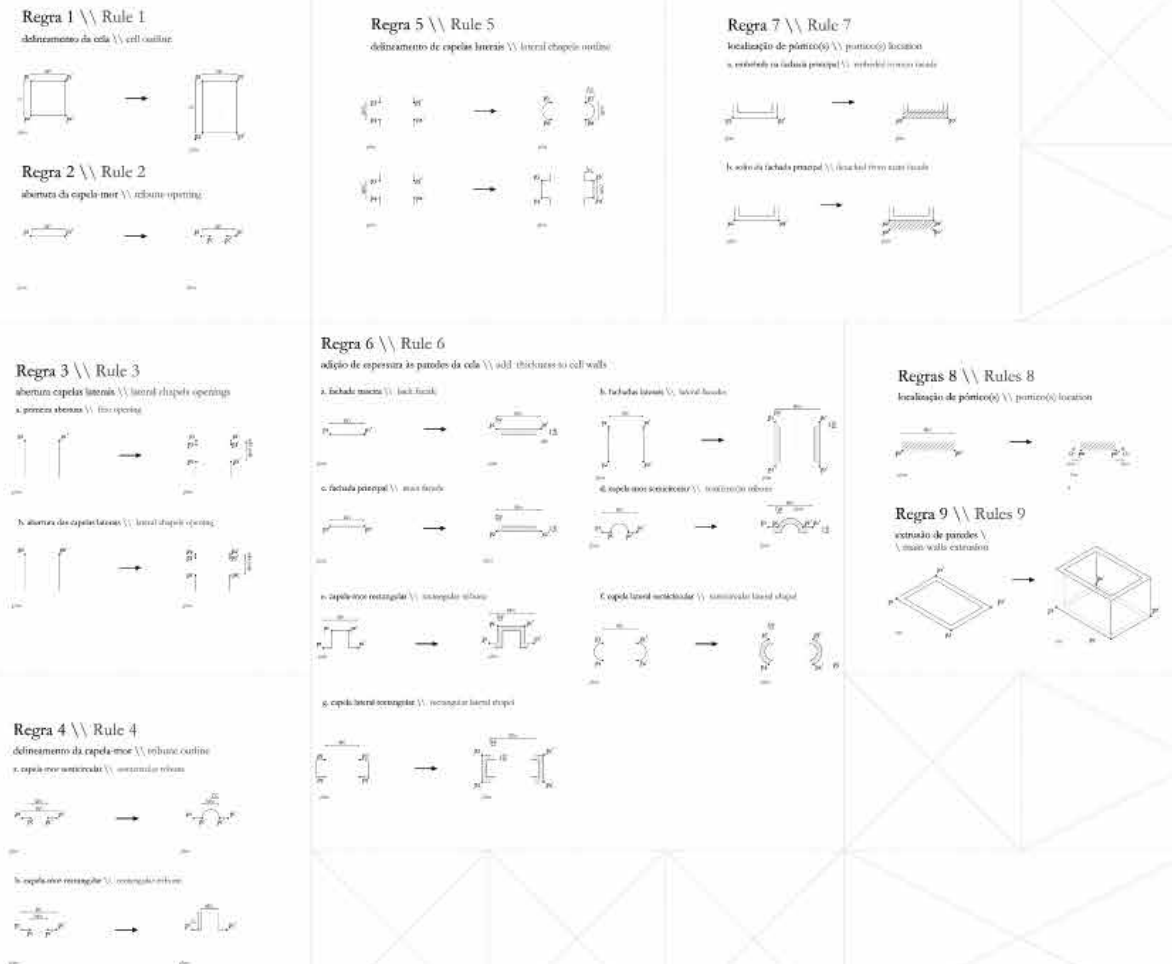

\section{Regras da forma \\ Gramática da forma de Edificios Sagrados}

O conjunto de ilustraçóes que se apresentam neste painel, e seguintes, representam uma amostra das regras da forma constituintes da gramática da forma dos edifícios sagrados de planta rectangular.

As regras da forma recorrem a representaçóes gráficas para descreverem as relaçóes formais e algorítmicas expressas no De re aedificatoria para geraçáo das partes constituintes da morfologia dos templos: cela - espaço interior do templo, definida pela geometria da sua área, tribuna ou capela-mor, capelas laterais e suas ossaturas, pórtico, informado pelas proporçóes das partes dos sistemas de colunas - base, fuste, capitel e entablamento - e suas, frontáo, paredes, telhado e principais aberturas.

\section{Shape Rules \\ Sacred Buildings Shape Grammar}

The set of illustrations that appear in this panel and followings, represent a sample of the rules constituents of the shape grammar of the sacred buildings of rectangular plan.

The shape rules use graphical representations to describe the formal and algorichmic relations expressed in De re dedificatoria for the generation of the temples constituent parts of: cell, defined by the geometry of their area, tribune, lateral chapels and their skeletons, portico informed by the proporrions from the parts of the columns systems - shaft, base, capitel and entablature, pediment, walls, roof, and main openings. 

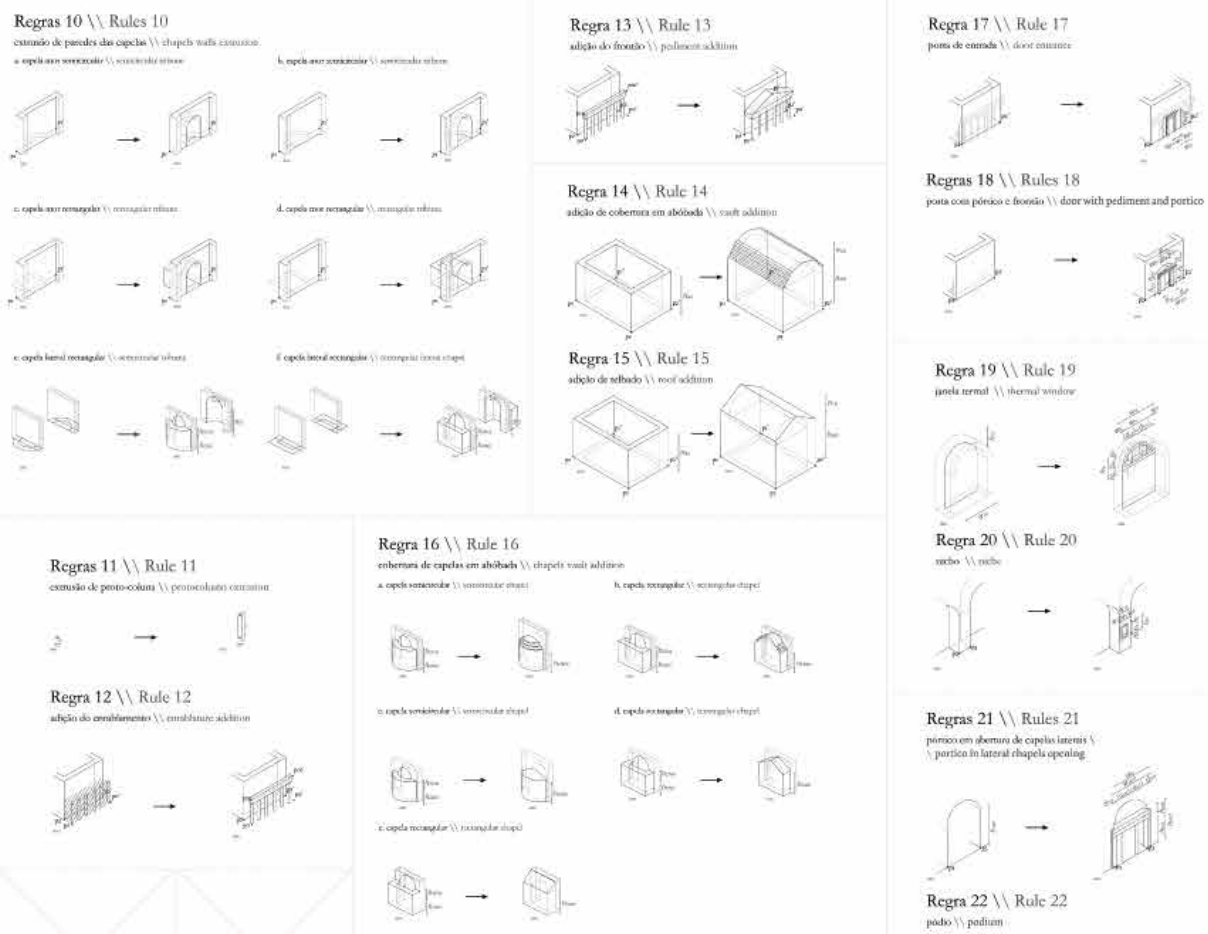

Regras $18 \backslash \backslash$ Rules 18

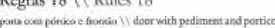

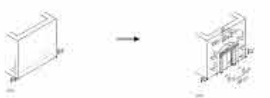

Regra $19 \backslash \backslash$ Rulc 19

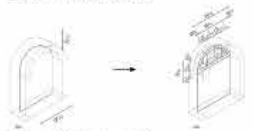

Regra $20 \backslash \backslash$ Rule 20

mats $M$ mint

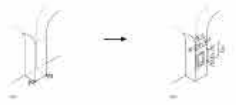

Regras $21 \backslash \backslash$ Rules 21

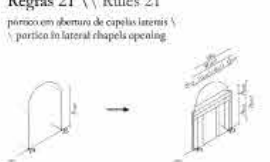

Regra $22 \backslash \backslash$ Rule 22 péts Y) podiun

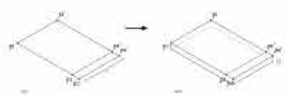

\section{Regras da forma Gramática da forma de Edifícios Sagrados}

A gramática da forma aqui apresentada subdivide-se em seis grupos de regras que correspondem a diferentes momentos de geraçáo: o grupo inicial de regras da forma dedica-se ao delineamento do perímetro interior dos edifícios - da regra 1 às regras 5 ; o segundo grupo ao delineamento do limite exterior - regras 6, 7 e 8; o terceiro momento define a extrusáo das paredes - regras 9 e 10; o quarto, os sistemas de colunas e a sua implementaçáo; o quinto refere-se à adiçáo de coberturas aos diversos volumes do edifício - regras 14,15 e 16, e as restantes regras à definiçáo de aberturas. Cada uma destas partes é retratada por uma ou mais regras. As regras săo descritas pela sua forma inicial e final, em quatro gramáticas paralelas, que correspondem a quatro vistas diferentes: planta, secçáo, alçado e vista axonométrica.

\section{Shape Rules}

Sacred Buildings Shape Grammar

The shape grammar presented here is divided into six groups of shape rules that correspond to different moments of generation: the initial set of shape rules is dedicated to the design of the inner perimeter of the buildings - rule 1 to rule 5 ;

the second group to the design of the external limir - rales 6,7 and 8; the third moment defines the walls extrusion - rules 9 and 10 ;

the fourth, the columns sysrems and its implementation;

the fifth refers to the addition of roof to the several volumes

of the buildings - 14 rules 15 and 16 , and the other rules define the openings. Each of these parts is portrayed by one or more rules. The rules are described by their starting and ending shape in four parallel grammars, which correspond to four different views: plan, section, elevation and axonometric view. 


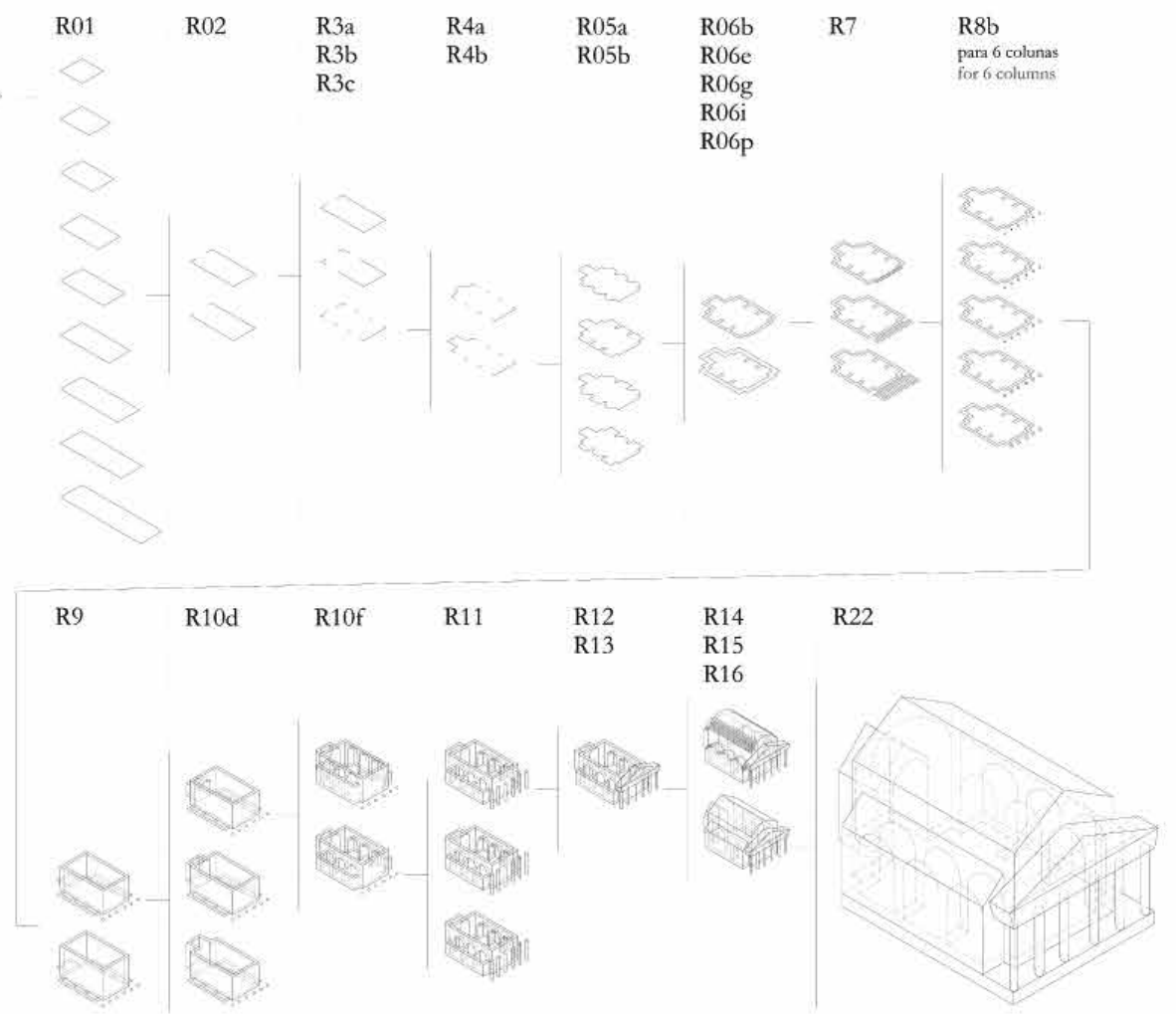

\section{Processo de derivação}

Gramática da forma de Edificios Sagrados

A árvore de derivaçáo representada na parte superior do paínel mostra a os vários momentos de derivvaçáo de uma soluçáo arquitectónica, pela aplicaçáo passo a passo de cada uma das regras,

e as possíveis transformaçôes à forma do lado esquerdo da regra.

\section{Derivation process}

Sacred Buildings Shape Grammar

The derivation tree represenred above shows the various moments of derivation of an architectural solution, by the application step by step of each rule, and the possible transformations to the shape of the left side of the rule. 


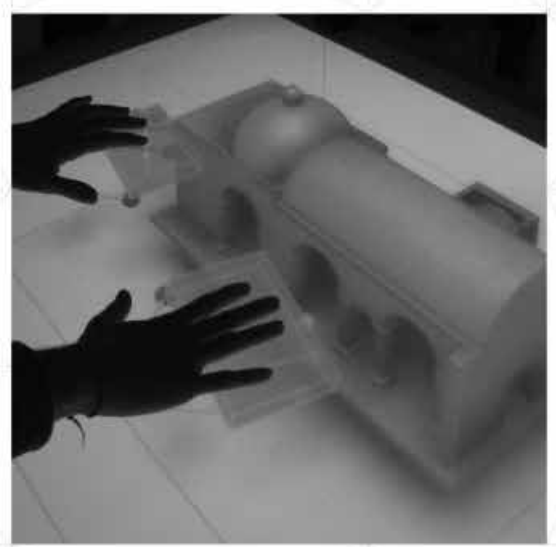

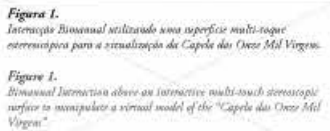

\section{Modelaçáo 3D Interactiva}

A Virtual Realidade da Arquitectura Albertiana

A Realidade Virtual abre novas oportunidades para a Visualizaçâo e Concepçáo Assistida por Computador de modelos digitais tridimensionais. A aplicaçáo Mockup Builder, permite criar, manipular e visualizar formas tridimensionais de uma forma natural, utilizando esboços e gestos.

Através de uma mesa multitoque, apresentamos obras realizadas segundo o Tratado de Leon Battista Alberti. Os modelos são visualizados através de óculos estereoscópicos, dando a percepçáo de uma maquete física colocada em cima da mesa.

Três camaras de profundidade Kinect capturam a postura e os gestos do utilizador no espaço. Assim pode-se descrever e manipular formas tridimensionais interactivamente.

Propomos um editor interactivo onde é possivel alterar o estilo de colunas e a configuração dos templos combinando duas técnicas de interface pessoa maquina: a continuidade entre a superficie e o espaço, e um modelo assimétrico de interacçáo bimanual.

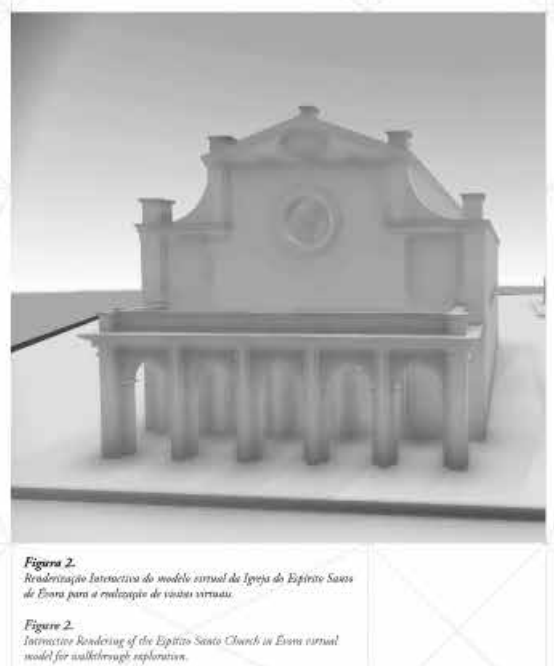

Interactive 3D Modeling

The Real Virtuality of Albertian Architecture

Virtual Reality rechnology offers new opportunities to support Computer Aided Design tasks making digital models more flexible and interactive. The Mockup Builder application allows creating and manipulating 3D shapes using both sketches and gestures on and above an interactive surface.

The multi-touch tabletop presents digital modets of churches following the Leon Bartista Alberti Treatise. Models can be edited interactively changing both column styles and temple configurations. The 3D models are rendered using a sterenscopic visualization mimicking the effect of architecrural scale models lying above the surface

Three Kineer depth sensors capture both the body posture and use gestures in space used to manipulate 3D shapes interactively. We combine two Human Computer Intetaction techniques, exploting the continuous space between the surface and the space above it and following a bimanual asymmetric interaction model. 


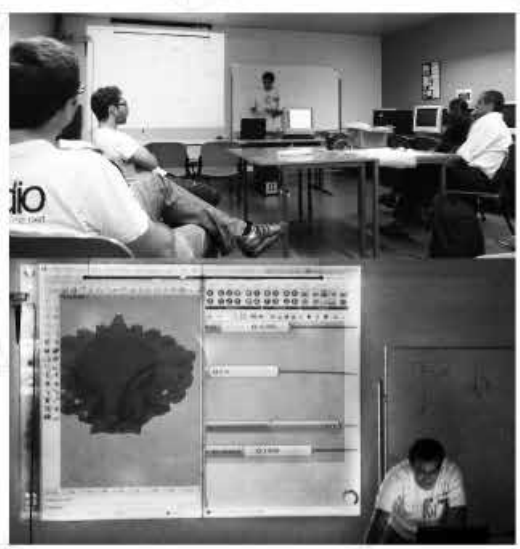

Figuna $I$.

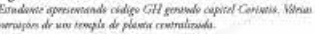

Figure $I$.

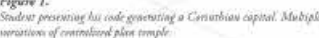

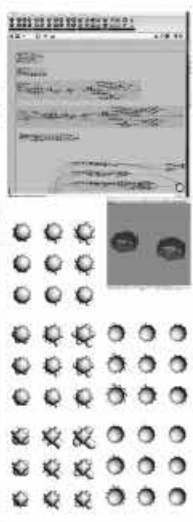

$2<000$

\section{Disciplina Alberti Digital}

A disciplina Alberti Digital ministrada na FA/UTL

e DARQ/UC esteve centrada na interpretaçāo e exploraçáo do tratado De re aedificatoria de L.B.Alberti.

Foi proposto aos alunos o desenvolvimento de um programa computacional de carácter visual usando para tal as regras subjacentes aos algoritmos presentes no tratado. Esse programa permitiu gerar modelos 3D com o fim de os fabricar digitalmente.

Pretendeu-se conformar, numa única disciplina académica, a interpretaçáo do tratado com vista à descodificaçáo e compilaçáo das suas regras e que os alunos ganhassem competências em programaçáo $\mathrm{GH}$ e diferentes técnicas de prototipagem rápida.

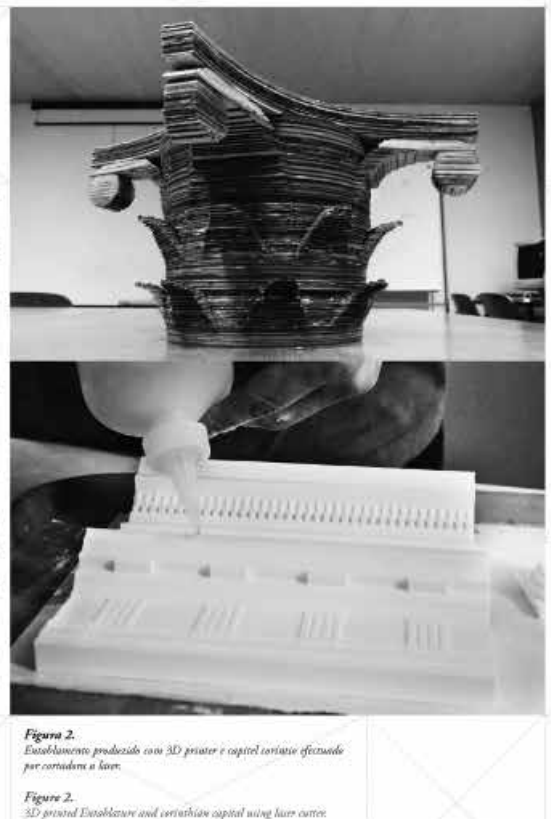

\section{Course Digital Alberti}

The class Alberti Digital taught ar the Faculty of Architecture of the Technical University of Lisbon (FAUTL) and in the Department of Architecture, University of Coimbra (Darq / UC) was centered in the interpretation and exploration of Alberti trearise De re sedificatori.

Studenes had to develop a visual computer program with the algorithms present in the treatise to generate virtual and physical models using different digital fabrication rechniques

The pedagogical goal was to gain skills in the use of computational resources and knowledge of history and theory relared with Renaissance architecture and the principles of Alherti in parricular. 


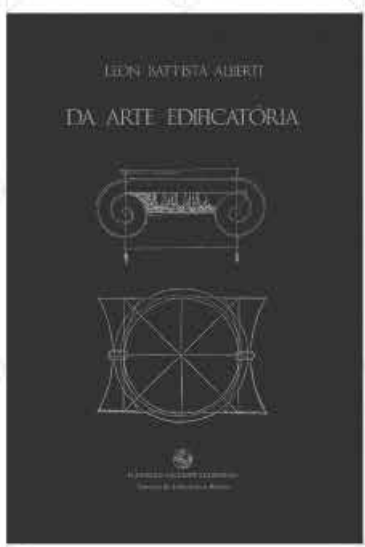

Figuran 1 .

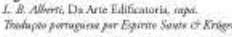
Figur I.

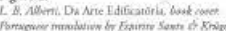
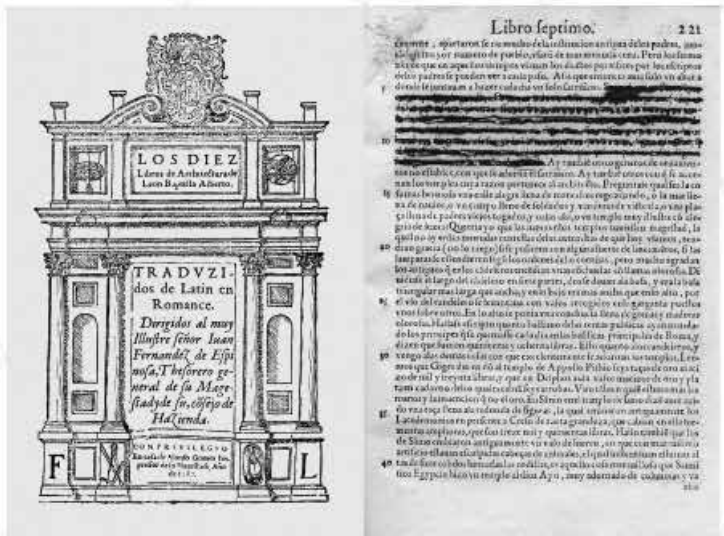

Figuma 2.

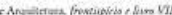

$\rightarrow 13,22 i$

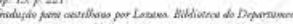

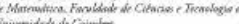

Figure 2.

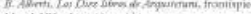

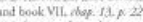

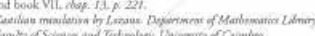

\section{Litterae em torno de Alberti}

Aqui se expóem algumas das obras escritas de Leon Battista Alberti, dando especial enfoque às obras dedicadas à Arquitectura.

Encontram-se também outros tratados de Arquitectura e Arte de que o De re aedificatoria de Alberti foi precursor.

Esta exposiçáo está integrada na exposiçáo Alberti Digital, patente no Museu da Ciência da Universidade de Coimbra. Este projecto de investigaçâo é, tanto, uma celebraçăo como uma inovaçáo.

Uma celebraçăo no sentido de comemorar a ordem dada por D. Joāo III, em meados do séc. XVI, a André de Resende para traduzir para português o De re aedificatoria de Leon Battista Alberti.

Uma inovaçáo no sentido de traçar a influência da teoria de Alberti na arquitectura clássica em Portugal usando um ambiente computacional para construir uma gramática generativa da forma, que possibilite entender as transformaçóes entre as suas propostas nâo só de organizaçâo formal mas também entre os edificios projectados e construídos, tanto em Portugal como naqueles territórios ultramarinos.

\section{Litterae on Alberti}

Here we exhibit some of the written works of Leon Battista Alberti. paying special artention to his books on architecture.

We also present other tearrise on Architecrure and An which De re aedificatoria of Alberti poses as a precursor.

This exhibition is simoulrancasly with the Digital Albert project held ar the Science Muscum of the University of Coimbra. Digital Alberti research project is a celebration and an innovation.

A celebration in the sense of commemorating the order

given by King John III, in mid XVI century, to André de Resende to translate Alberti's De re aedificatoria to the Portuguese language

An innovation in the sense of tracing the influence of Albettis theory in Portuguese classical architecture using a compucational environment to construct a generative shape grammar, which will enable to understand the transformations between the treatise and the buildings designed and built in Portugal and overseas. 


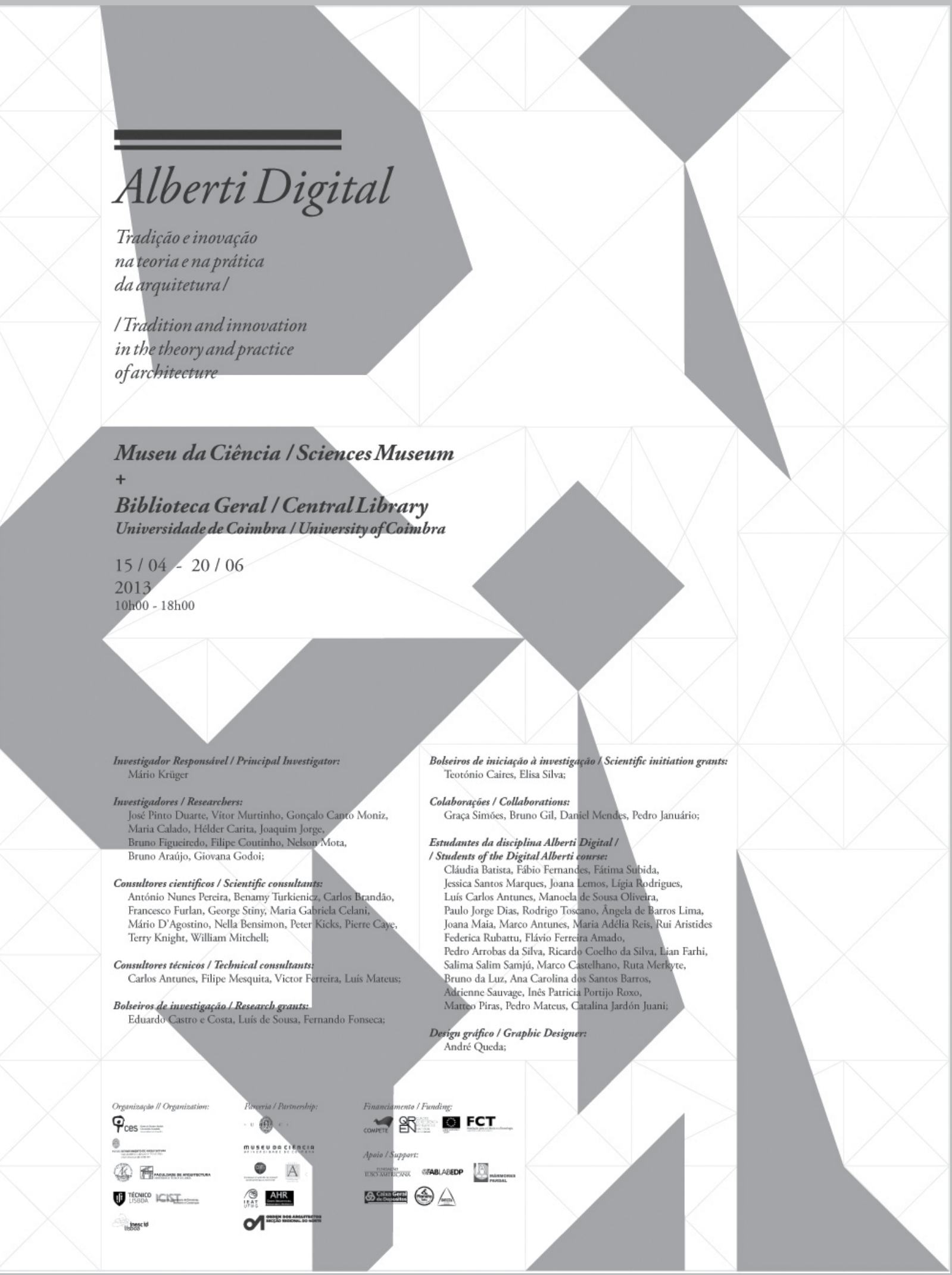

